Article

\title{
The Potential Application of Microorganisms for Sustainable Petroleum Recovery from Heavy Oil Reservoirs
}

\author{
Tamara Nazina ${ }^{1, *}{ }^{1}$, Diyana Sokolova ${ }^{1}$, Denis Grouzdev ${ }^{2}{ }^{\mathbb{D}}$, Ekaterina Semenova ${ }^{1}$, \\ Tamara Babich ${ }^{1}$, Salimat Bidzhieva ${ }^{1}$, Dmitriy Serdukov ${ }^{1}$, Dmitriy Volkov ${ }^{3}$, \\ Konstantin Bugaev ${ }^{3}$, Alexey Ershov ${ }^{1}$, Marat Khisametdinov ${ }^{4}$ and Igor Borzenkov ${ }^{1}$ \\ 1 Winogradsky Institute of Microbiology, Research Center of Biotechnology, Russian Academy of Sciences, \\ Prospect 60-letiya Oktyabrya, 7/2, Moscow 117312, Russia; sokolovadiyana@gmail.com (D.S.); \\ mkatusha82@mail.ru (E.S.); microb101@yandex.ru (T.B.); salima.bidjieva@gmail.com (S.B.); \\ dimse@ya.ru (D.S.); e.alexey.mail@yandex.ru (A.E.); inmiran@yandex.ru (I.B.) \\ 2 Institute of Bioengineering, Research Center of Biotechnology, Russian Academy of Sciences, Prospect \\ 60-letiya Oktyabrya, 7/1, Moscow 117312, Russia; denisgrouzdev@gmail.com \\ 3 RITEK Co., Bolshaya Ordynka, 3, Moscow 115035, Russia; da.volkov@inbox.ru (D.V.); \\ konstantin.bugaev@lukoil.com (K.B.) \\ 4 Tatar Oil Research and Design Institute, M. Djalil, 32, Bugulma 423236, Russia; bio@tatnipi.ru \\ * Correspondence: nazina@inmi.ru; Tel.: +7-499-1350341
}

Received: 18 November 2019; Accepted: 11 December 2019; Published: 18 December 2019

\begin{abstract}
A microbial enhanced oil recovery (MEOR) technique was tested at low-temperature heavy oil reservoirs (Russia). The bioaugmentation approach used is based on the introduction of hydrocarbon-oxidizing bacteria into the oilfield in combination with an injection of oxygen as a $\mathrm{H}_{2} \mathrm{O}_{2}$ solution in order to initiate the first stage of hydrocarbon oxidation and of $\left(\mathrm{NH}_{4}\right)_{2} \mathrm{HPO}_{4}$ as a source of biogenic elements. Before the pilot trials, the microorganisms of petroleum reservoirs were investigated by high-throughput sequencing, as well as by culture-base and radioisotope techniques. Molecular studies revealed the differences in microbial composition of the carbonate and terrigenous oil reservoirs and the communities of injection and formation water. Aerobic bacteria Rhodococcus erythropolis HO-KS22 and Gordonia amicalis 6-1 isolated from oilfields oxidized oil and produced biosurfactants. Fermentative enrichment and pure cultures produced considerable amounts of low fatty acids and alcohols from sacchariferous substrates. In core-flooding tests, $43.0-53.5 \%$ of additional heavy oil was displaced by aerobic bacteria, producing biosurfactants, and $13.4-45.5 \%$ of oil was displaced by fermentative bacteria, producing low fatty acids, alcohols, and gas. A total of $1250 \mathrm{t}$ additional oil was recovered as a result of the application of an MEOR technique at the Cheremukhovskoe heavy oil reservoir and Vostochno-Anzirskoe reservoir with light conventional oil.
\end{abstract}

Keywords: microbial enhanced oil recovery (MEOR); heavy oil reservoirs; microbial community; high-throughput sequencing; hydrocarbon-oxidizing bacteria; fermentative bacteria; surface and interfacial tension; core flooding; MEOR pilot trials

\section{Introduction}

The estimated reserves of heavy oil and bitumen in Russia are 6-7 billion tons, exceeding the remaining reserves of conventional oil, and may be considered the main basis for the development of oil production in the next few years. The most promising methods for heavy oil recovery are thermal methods, which decrease the oil viscosity (fire flooding, steam flooding, and cyclic or joint injection of steam, solvents, and surfactants). However, the application of these methods requires a large energy 
consumption for steam generation, a large amount of fresh water and expensive equipment for its preparation, and the use of expensive chemicals (surfactants, solvents), which significantly increases the cost of oil and adds environmental risks such as contact between groundwater and the reactants.

Microbially enhanced oil recovery (MEOR) technologies were developed and successfully implemented in reservoirs with light conventional oil in Russia, USA, and China in 1980-2010 [1,2]. Oilfield microorganisms were shown to have a significant effect on oil displacement. Microbially produced gases, acids, solvents, polymers, and surfactants exhibit oil-displacement properties similar to those of their synthetic analogs. All microbial metabolites probably have a synergistic effect on oil displacement. The method of microbial stimulation compares favorably with chemicals injection into the reservoir, since bacteria may thrive in the oil reservoir, producing metabolites in the reservoir pores where they have the greatest effect on oil displacement. Furthermore, the nutrient source for bacteria is either the oil itself or waste food production, such as molasses, which significantly reduces the cost of the additionally recovered oil in comparison with other methods.

Relatively few works have dealt with field MEOR experiments at heavy oil reservoirs. The microbial ecology of heavy oil reservoirs and factors controlling in-reservoir petroleum biodegradation were the main study topics [3]. The ability of sulfidogenic and methanogenic communities to carry out the biodegradation of heavy oil components was shown both under laboratory conditions and in reservoirs [4-9]. The microorganisms inhabiting heavy oil deposits were investigated [10-14]. A number of aerobic, biosurfactant-producing bacteria were isolated from oilfields, and heavy oil displacement from model oilfields by the isolates was demonstrated [15-17].

Although field experiments at the heavy oil reservoirs have been few, it was shown that heavy oil recovery became more sustainable when MEOR techniques were applied. The patterns of activity of a thermophilic microbial community were investigated at the Dagang high-temperature $\left(56.9-59.4{ }^{\circ} \mathrm{C}\right)$ heavy oil reservoir (China), and three field trials were performed (at the North block and block No. 1 of the Kongdian bed and at the Gangxi bed) [18-20]. At the Kongdian bed, characterized by high temperature, complex geological conditions, and heavy oil with a density $0.955-0.969 \mathrm{~g} / \mathrm{cm}^{3}$, the biotechnology involved injecting oxygen as an air-water mixture or $\mathrm{H}_{2} \mathrm{O}_{2}$ together with an aqueous solution of nitrogen and phosphorus mineral salts through injection wells in order to activate the oilfield microbial community [18]. The microbial oxidation of heavy oil resulted in the formation of lower alcohols and volatile fatty acids, which were subsequently utilized by anaerobic microorganisms producing gases $\left(\mathrm{CH}_{4}\right.$ and $\left.\mathrm{CO}_{2}\right)$. The production of biosurfactants, resulting in decreased surface tension of formation water, was observed both in cultures and in oil reservoirs. Oil viscosity in the zone of production wells located at the North block of the Kongdian bed decreased by $11 \%$ (from 501.2 to $458.9 \mathrm{mPa}$ ), wax content in oil decreased from $6.64 \%$ to $4.72 \%$ [12,20]. Under conditions of a high-temperature oil reservoir, methane was found to be produced from acetate in the course of the syntrophic growth of acetate-oxidizing bacteria and $\mathrm{H}_{2}$-utilizing methanogens. Pure cultures of acetate-oxidizing Thermoanaerobacter ethanolicus strain 1017-7b and $\mathrm{H}_{2}$-utilizing methanogen Methanothermobacter thermautotrophicus strain KZ3 were isolated from an association producing methane from acetate. While none of these strains were able to grow on acetate in monoculture, methane formation from acetate was observed in the combination of these cultures [21]. A total of 46,152 $t$ additional oil was recovered at three experimental sites of the Dagang oilfield, which is an indication of the high efficiency of the technology for activation of the oilfield microorganisms for the purpose of heavy oil displacement from high-temperature oilfields [20].

MEOR field trials were also performed at low-temperature heavy oil reservoirs. In the experiment at the Xinjiang No. 6 oilfield (China), air, molasses, and mineral salts were injected into the reservoir to initiate an indigenous process of microbial enhanced oil recovery (MEOR), which resulted in an increment of $1872 \mathrm{t}$ heavy oil [22]. Oil oxidation by Pseudomonas and the metabolic products, including biosurfactants, were proposed to be the primary factors responsible for improving heavy oil recovery.

The aim of this work was to study the microbial community composition and the presence of microorganisms able to produce oil-releasing compounds in production waters of low-temperature 
heavy oil reservoirs (Russia), to estimate heavy oil displacement from the cores by aerobic organotrophic and fermentative bacteria, and to perform a pilot trial of the MEOR technique at the oilfield.

\section{Materials and Methods}

\subsection{Characteristics of the Studied Heavy oil Reservoirs and Sampling Procedures}

The microorganisms of injection and production water from petroleum reservoirs in Volgograd oblast and Tatarstan (Russia) were studied. Oil strata were located at the depth of 830-1650 $\mathrm{m}$ and had a temperature of $20-40{ }^{\circ} \mathrm{C}$ (Table A1). According to analyses of surface samples, oil density varied from $0.813 \mathrm{~g} / \mathrm{cm}^{3}$ to $0.924 \mathrm{~g} / \mathrm{cm}^{3}$ (at $20^{\circ} \mathrm{C}$ ). This made it possible to classify the oil from two out of four oilfields as heavy oil. The studied areas of the Arkhangelskoe and Romashkinskoe oilfields (Tatneft, Tatarstan) and Cheremukhovskoe and Vostochno-Anzirskoe oilfields (Ritek, Volgograd oblast) are exploited with water-flooding [23].

Water samples were collected directly at the head of injection wells and production wells into sterile bottles, hermetically sealed without air bubbles, and used for radioisotope and microbiological analyses on the day of sampling. Within 4-6 h after sampling, inoculations were carried out in order to determine cell numbers of cultivated microorganisms. To estimate the rates of sulfate reduction and methanogenesis, aliquots of the water samples were supplemented with labeled compounds $\left(\mathrm{Na}_{2}{ }^{35} \mathrm{SO}_{4}, \mathrm{NaH}^{14} \mathrm{CO}_{3}\right.$, and $\left.{ }^{14} \mathrm{CH}_{3} \mathrm{COONa}\right)$ and analyzed as described previously [24]. The samples for chemical analyses were stored at $6{ }^{\circ} \mathrm{C}$. For molecular biological research, water samples $(1 \mathrm{~L}$ each) were fixed with ethanol $(1: 1 \mathrm{vol} / \mathrm{vol})$ at the day of sampling, filtered through $0.22 \mu \mathrm{m}$ membranes (Millipore, United States), and stored at $-20{ }^{\circ} \mathrm{C}$ prior to analysis.

\subsection{Analysis of Microbial Diversity in Heavy oil Reservoirs}

The composition of microbial communities from injection and formation water was determined by high-throughput sequencing of the $16 \mathrm{~S}$ rRNA genes on the Illumina platform. Cell biomass obtained by the filtration of ethanol-fixed water samples was washed off with the lysing solution containing $0.15 \mathrm{M} \mathrm{NaCl}$ and $0.1 \mathrm{M} \mathrm{Na}_{2}$ EDTA ( $\mathrm{pH}$ 8.0) and used for DNA isolation. Total DNA was isolated using the PowerSoil DNA Isolation Kit (MoBio, USA) according to the manufacturer's recommendations and was stored at $-20^{\circ} \mathrm{C}$. The purified DNA preparation was used as a template for polymerase chain reaction (PCR) with a pair of universal primers to the V3-V4 regions of the 16S rRNA gene: 319F (5'-ACTCCTACGGGAGGCAGCAG-3') and 806R (5'-GGACTACHVGGGTWTCTAAT-3). The primers were supplemented with oligonucleotide identifiers for sequencing on MiSeq (Illumina, USA). Sample preparation and sequencing were carried out according to the manufacturer's recommendations. Quality control of obtained reads was carried out using UPARSE [25]. After qualification, the reads were grouped into operational taxonomic units (OTUs) with 97\% similarity using USEARCH (https: //www.drive5.com/usearch/) [26]. The taxonomic position of the representative sequence for each OTU was determined using the RDP (https://rdp.cme.msu.edu/tutorials/classifier/classifer_cover_page.html) classifier [27]. Analysis of community composition using heatmaps was carried out using ClustVis [28]. Statistical analysis was carried out using Microsoft Excel, Rstudio (the vegan package) [29].

\subsection{Media Composition and Cultures Used in the Study}

Cell numbers of the microorganisms of the main metabolic groups were determined by inoculation of ten-fold dilutions of the water samples into liquid media in triplicate, as described earlier [23]. Salinity of the studied water samples was taken into consideration when preparing the media. Samples of injection water were inoculated into the media containing $10 \mathrm{~g} \mathrm{NaCl}$ per liter. Samples of high-salinity formation water were inoculated into the media with $45 \mathrm{~g} \mathrm{NaCl}$ per liter. Aerobic organotrophs were enumerated in trypton-extract-glucose (TEG) medium containing the following $\left(\mathrm{g} \cdot \mathrm{L}^{-1}\right.$ ): Bacto tryptone, 5.0; yeast extract, 2.5; glucose, 1.0; and $\mathrm{NaCl}$, as required; $\mathrm{pH}$ 7.0-7.2. The numbers of hydrocarbon-oxidizing bacteria were determined using a mineral medium supplemented with a 
mixture of $C_{10}-C_{22} n$-alkanes ( $2 \%$ vol/vol). Anaerobic fermentative bacteria were enumerated in the medium supplemented with peptone $\left(4 \mathrm{~g} \cdot \mathrm{L}^{-1}\right)$ and glucose $\left(10 \mathrm{~g} \cdot \mathrm{L}^{-1}\right)$. The numbers of sulfate-reducing bacteria were determined by an increase in sulfide concentration in dilution series of formation water in Postgate B medium with sodium lactate $\left(3.5 \mathrm{~g} \cdot \mathrm{L}^{-1}\right)$, supplemented with microelements and reduced with $\mathrm{Na}_{2} \mathrm{~S} \cdot 9 \mathrm{H}_{2} \mathrm{O}\left(200 \mathrm{mg} \cdot \mathrm{L}^{-1}\right)$. The numbers of methanogens were assayed by methane production in dilution series in the Zeikus medium with acetate $\left(2 \mathrm{~g} \cdot \mathrm{L}^{-1}\right)$, methanol $\left(1 \mathrm{~mL} \cdot \mathrm{L}^{-1}\right)$, and $\mathrm{H}_{2} / \mathrm{CO}_{2}(4: 1)$, supplemented with microelements and yeast extract $\left(1 \mathrm{~g} \cdot \mathrm{L}^{-1}\right)$. The composition of the media used is cited in the publication by Bonch-Osmolovskaya et al. [24]. Inoculated media were incubated for 30 days at $22-24{ }^{\circ} \mathrm{C}$ and then examined using an Olympus microscope with a phase contrast device.

Aerobic heavy oil degrading bacteria Gordonia amicalis strain 6-1 (=VKM Ac-2795D) and Rhodococcus erythropolis strain HO-KS22 (=VKM Ac-2807D) were isolated earlier from the Cheremukhovskoe and Vostochno-Anzirskoe oilfields (Russia), respectively [23]. Fermentative enrichment 7SA was obtained by inoculation of the medium with peptone and glucose with water injected into well 1010 of the Vostochno-Anzirskoe oilfield. Pure culture of a fermentative bacterium Oscillibacter ruminantium strain AIK was obtained from the sludge of a biogas reactor processing oil-containing and municipal waste [30]. For core flooding experiments, O. ruminantium strain AIK was grown in the medium for fermentative bacteria (FM) containing the following ( $\mathrm{g} \cdot \mathrm{L}^{-1}$ distilled water): $\mathrm{KH}_{2} \mathrm{PO}_{4}, 0.2 ; \mathrm{NH}_{4} \mathrm{Cl}$, $0.25 ; \mathrm{NaCl}, 1.0 ; \mathrm{MgCl}_{2} \cdot 6 \mathrm{H}_{2} \mathrm{O}, 0.4 ; \mathrm{KCl}, 0.5 ; \mathrm{CaCl}_{2} \cdot 6 \mathrm{H}_{2} \mathrm{O}, 0.1$; peptone, 1.0; glucose, 2.0; sucrose, 2.0; yeast extract, 1.0; $\mathrm{Na}_{2} \mathrm{~S} \cdot 9 \mathrm{H}_{2} \mathrm{O}, 0.5$; and $1 \mathrm{~mL} \cdot \mathrm{L}^{-1}$ trace elements [31]. Argon was used as the gas phase. Fermentative enrichment 7SA was grown in liquid mineral FM medium supplemented with glucose $\left(2.0 \mathrm{~g} \cdot \mathrm{L}^{-1}\right)$ and sucrose $\left(2.0 \mathrm{~g} \cdot \mathrm{L}^{-1}\right)$ as substrates, with $10.0 \mathrm{~g} \cdot \mathrm{L}^{-1} \mathrm{NaCl}$; without addition of the reducing agent. Strain AIK and fermentative enrichment 7SA were grown for 20 days under stationary conditions at $25^{\circ} \mathrm{C}$. Grown liquid cultures with microbial biomass and metabolites were used in core flooding experiments on the enhancement of oil recovery.

Oil biodegradation by aerobic hydrocarbon-oxidizing bacteria was studied in the medium of the following composition ( $\mathrm{g} \cdot \mathrm{L}^{-1}$ distilled water): $\mathrm{CaCl}_{2} \cdot 6 \mathrm{H}_{2} \mathrm{O}, 0.01 ; \mathrm{MnSO}_{4} \cdot 5 \mathrm{H}_{2} \mathrm{O}, 0.02 ; \mathrm{FeSO}_{4} \cdot 7 \mathrm{H}_{2} \mathrm{O}$, $0.01 ; \mathrm{Na}_{2} \mathrm{HPO}_{4} \cdot 12 \mathrm{H}_{2} \mathrm{O}, 1.5 ; \mathrm{KH}_{2} \mathrm{PO}_{4}, 1.0 ; \mathrm{MgSO}_{4} \cdot 7 \mathrm{H}_{2} \mathrm{O}, 0.2 ; \mathrm{NH}_{4} \mathrm{NO}_{3}, 2.0 ; \mathrm{NaCl}, 5.0 ; \mathrm{pH}$ 6.8-7.2; oil $1.0 \%$ (vol/vol). The experiments were carried out using crude oil of the Cheremukhovskoe oilfield, which contained $23.5 \%$ saturated hydrocarbons, $42.3 \%$ aromatic hydrocarbons, $30.1 \%$ resins, and $4.1 \%$ asphaltenes. The cultures and uninoculated medium with oil (control) were incubated for seven days on a shaker $(60 \mathrm{rpm})$ at $28^{\circ} \mathrm{C}$. After incubation, oil fractions were separated as described previously [32]. Residual oil was extracted with chloroform; the extract was dried with $\mathrm{Na}_{2} \mathrm{SO}_{4}$, filtered, and the solvent was removed on a rotary evaporator. Oil was then dispensed into vials, dried for $24 \mathrm{~h}$ under draught, and analyzed by gas-liquid chromatography (GLC).

\subsection{Analytical Methods}

The contents of methane, hydrogen, and carbon dioxide accumulated in the gas phase of the primary enrichment cultures were determined by gas chromatography. Sulfide was determined by the colorimetric method of Pachmayr with dimethyl-p-phenylenediamine [33]. The chemical composition of formation water was determined as described by Bonch-Osmolovskaya et al. [24]. Volatile fatty acids and alcohols were analyzed with a Shimadzu GC 2010 Plus chromatograph (Japan) in a column ( $30 \mathrm{~m} \times 0.32 \mathrm{~mm}$ ) with a Zebron ZB-FFAP phase thickness of $0.25 \mu \mathrm{m}$, as described previously [34]. The surface tension was measured at the interface between formation water and air. The interfacial tension was determined at the interface between the studied liquid and the $n$-hexadecane by the ring-tearing-off method using a Kruss K10 ST tensiometer (Kruss GmbH, Germany) at $22^{\circ} \mathrm{C}$.

The aliphatic fraction of oil was analyzed on a Crystal 5000.1 gas-liquid chromatograph (Chromatec, Russia) equipped with a flame ionization detector and a $15 \mathrm{~m}$ ZB-FFAP capillary column, with helium as the carrier gas. The column temperature changed from $100{ }^{\circ} \mathrm{C}$ to $320^{\circ} \mathrm{C}$ in the course of analysis at the rate of $5^{\circ} \mathrm{C} / \mathrm{min}$. 


\subsection{Core Flooding Experiments}

The oilfield models were constructed using several cores of carbonate rocks with intact structure; each core was $\sim 30 \mathrm{~mm}$ in diameter and $\sim 40 \mathrm{~mm}$ long. The cores were cleaned from hydrocarbons by using the Soxhlet extraction method, using benzene and methanol in the proportion of 75:25 vol/vol. After cleaning, the cores were dried at $100-110{ }^{\circ} \mathrm{C}$ for $24 \mathrm{~h}$, and their absolute permeability was determined. The columns packed with two cores each were $8.0 \mathrm{~cm}$ in length and $3.02 \mathrm{~cm}$ in diameter and were made of stainless steel. The cores were saturated with filtered formation brine with $195 \mathrm{~g} \cdot \mathrm{L}^{-1}$ salinity using vacuum desiccators for $24 \mathrm{~h}$, and pore volume (PV) was determined using the dry and wet weights of each core, as described previously [16]. The cores were then flooded with heavy crude oil with a density of $0.93 \mathrm{~g} / \mathrm{cm}^{3}$ and viscosity of $190 \mathrm{mPa} \cdot \mathrm{sec}$ at $1 \mathrm{~cm}^{3} / \mathrm{min}$ until no more water was removed. This filtration rate was chosen since microbial processes in the near-bottom zone of injection wells were simulated, which is characterized by a high rate of injected water flow. The oil initially in place (OIIP) was determined, which was indicated by the volume of water displaced. The core was subjected to water flooding at $1 \mathrm{~cm}^{3} / \mathrm{min}$ until no further oil was removed. The residual oil was calculated by measuring the amount of oil recovered by water-flooding. After preliminary operations, the model was incubated for one to seven days at the experimental values of temperature and pressure. Then, $10 \mathrm{PV}$ of the grown liquid culture was injected as a tertiary recovery stage and extra oil recovery was determined. All core floods were conducted at $7-8 \mathrm{MPa}$ and $22-24^{\circ} \mathrm{C}$ to mimic the pressure and temperature of the oilfield, respectively.

\subsection{Nucleotide Sequence Accession Numbers}

The 16S rRNA gene sequences of strains Gordonia amicalis 6-1 (= VKM Ac-2795D), Rhodococcus erythropolis HO-KS22 (= VKM Ac-2807D), and Oscillibacter ruminantium AIK were deposited in the NCBI database under accession numbers MN101280, MN622878, and MN623416, respectively. The libraries of the $16 \mathrm{~S}$ rRNA gene fragments, obtained as a result of high-throughput sequencing, were deposited in the NCBI Sequence Read Archive (SRA) under accession number PRJNA589080.

\section{Results and Discussion}

\subsection{Physicochemical and Microbiological Characteristics of Injection and Production Water of the Studies Oilfields}

The petroleum reservoirs studied are exploited with water-flooding with fresh water from the surface or with its mixture with formation water, separated from oil. The injection of fresh water results in decreased salinity in the area of water mixing. Formation water from the Arkhangelskoe heavy-oil reservoir with carbonate collectors had salinity from $36 \mathrm{~g} \cdot \mathrm{L}^{-1}$ to $244 \mathrm{~g} \cdot \mathrm{L}^{-1}$, belonged to the chlorine-calcium type, and contained high levels of bicarbonate $\left(0.12 \mathrm{~g} \cdot \mathrm{L}^{-1}\right.$ to $\left.0.70 \mathrm{~g} \cdot \mathrm{L}^{-1}\right)$ and sulfates $\left(0.44 \mathrm{~g} \cdot \mathrm{L}^{-1}\right.$ to $\left.1.58 \mathrm{~g} \cdot \mathrm{L}^{-1}\right)$ (Table 1$)$. In the terrigenous Cheremukhovskoe heavy oil reservoir, production water with salinity from $12 \mathrm{~g} \cdot \mathrm{L}^{-1}$ to $186.9 \mathrm{~g} \cdot \mathrm{L}^{-1}$ belonged to the chlorine-calcium type; the content of bicarbonate in studied water samples varied within a narrow range from $0.29 \mathrm{~g} \cdot \mathrm{L}^{-1}$ to $0.32 \mathrm{~g} \cdot \mathrm{L}^{-1}$, and that of sulfate from $0.08 \mathrm{~g} \cdot \mathrm{L}^{-1}$ to $0.22 \mathrm{~g} \cdot \mathrm{L}^{-1}$. At the terrigenous Romashkinskoe oilfield (Almetievskaya bed) with light conditioned oil, which was used for comparison, the salinity of production water samples varied within a wide range exceeding $190 \mathrm{~g} \cdot \mathrm{L}^{-1}$. Fresh river water injected into the Almetievskaya bed through injection wells $20990^{*}$ and $10055^{*}$ had a density of $\sim 1.000 \mathrm{~kg} \mathrm{dm}^{-3}$. 
Table 1. Physicochemical characteristics of injection and formation water at the studied oilfields.

\begin{tabular}{|c|c|c|c|c|c|c|c|c|}
\hline \multirow{2}{*}{$\begin{array}{l}\text { Oilfield, } \\
\text { Well No. }\end{array}$} & \multirow{2}{*}{$\begin{array}{l}\text { Total Salinity, } \\
\qquad \mathrm{g} \mathrm{L}^{-1}\end{array}$} & \multirow{2}{*}{$\mathrm{pH}$} & \multicolumn{6}{|c|}{ Content, $\mathrm{g} \mathrm{L}^{-1}$} \\
\hline & & & $\mathrm{Na}^{+}+\mathrm{K}^{+}$ & $\mathrm{Ca}^{2+}$ & $\mathrm{Mg}^{2+}$ & $\mathrm{Cl}^{-}$ & $\mathrm{HCO}_{3}^{-}$ & $\mathrm{SO}_{4}{ }^{2-}$ \\
\hline \multicolumn{9}{|c|}{ Arkhangelskoe oilfield } \\
\hline $7528^{*}$ & 0.966 & 7.6 & 0.195 & 0.134 & 0.037 & 0.110 & 0.354 & 0.136 \\
\hline 4610 & 36.291 & 7.2 & 9.932 & 3.206 & 0.608 & 21.272 & 0.592 & 0.681 \\
\hline 7492 & 51.712 & 6.8 & 16.289 & 3.138 & 0.737 & 29.261 & 0.708 & 1.579 \\
\hline 4634 & 73.850 & 6.5 & 22.302 & 4.584 & 1.668 & 43.219 & 0.573 & 1.504 \\
\hline 7806 & 104.628 & 6.9 & 32.134 & 6.528 & 2.117 & 62.423 & 0.622 & 0.804 \\
\hline 4308 & 244.092 & 5.9 & 81.615 & 11.538 & 3.683 & 146.695 & 0.122 & 0.439 \\
\hline \multicolumn{9}{|c|}{ Romashkinskoe oilfield } \\
\hline 20880 & 11.819 & 7.5 & 3.222 & 1.052 & 0.213 & 7.115 & 0.207 & 0.013 \\
\hline 20963 & 49.869 & 6.6 & 13.9 & 4.259 & 0.912 & 30.636 & 0.159 & 0.0029 \\
\hline 47B & 81.813 & 6.4 & 22.762 & 7.014 & 1.52 & 50.101 & 0.098 & 0.0177 \\
\hline $2356 \mathrm{D}$ & 165.14 & 5.7 & 46.123 & 14.279 & 2.888 & 101.79 & 0.049 & 0.0108 \\
\hline 21058 & 190.78 & 5.4 & 53.230 & 16.533 & 3.344 & 117.6 & 0.049 & 0.0177 \\
\hline \multicolumn{9}{|c|}{ Cheremukhovskoe oilfield ** } \\
\hline $5600^{*}$ & 0.621 & 7.86 & 0.114 & 0.060 & 0.015 & 0.114 & 0.244 & 0.074 \\
\hline 5454 & 12.098 & 7.70 & 4.125 & 0.516 & 0.138 & 6.946 & 0.293 & 0.080 \\
\hline 5463 & 72.274 & 6.69 & 24.324 & 3.373 & 0.993 & 43.124 & 0.317 & 0.143 \\
\hline 5464 & 186.890 & 6.30 & 64.849 & 8.531 & 1.564 & 111.435 & 0.293 & 0.218 \\
\hline
\end{tabular}

A tendency to higher abundance of culturable microorganisms in the desalinated zone compared to the highly mineralized formation water was observed. In the Arkhangelskoe heavy oil reservoir with carbonate collectors, the highest microbial numbers were found in injection fresh water (well 7528) and in the production water sample with salinity up $73 \mathrm{~g} \cdot \mathrm{L}^{-1}$ (well 4634) (Figure A1). In production water with higher salinity, the numbers of microorganisms of the major physiological groups did not exceed tens of cells per mL. Sulfate reduction rate was registered by the radioisotope method in water samples with salinity below $105 \mathrm{~g} \cdot \mathrm{L}^{-1}$, but methanogenesis rate was detected up to $244 \mathrm{~g} \cdot \mathrm{L}^{-1}$ (Table A2).

In the terrigenous Cheremukhovskoe heavy oil reservoir, the numbers of microorganisms were considerably lower in production water samples with salinity exceeding $72 \mathrm{~g} \cdot \mathrm{L}^{-1}$, although fermentative microorganisms occurred at up to $186.9 \mathrm{~g} \cdot \mathrm{L}^{-1}$ (well 5464). In spite of the broad salinity range of formation water at the terrigenous Romashkinskoe oilfield (Almetievskaya bed) with light oil, the numbers of aerobic organotrophs, as well as of fermentative and methanogenic prokaryotes, were higher than in the studied heavy oil reservoirs. While sulfide formation was detected in fermentative enrichments after long-term incubation, cultured sulfate-reducing bacteria were not retrieved when medium with lactate and $45 \mathrm{~g} \cdot \mathrm{L}^{-1} \mathrm{NaCl}$ was inoculated with formation water of the Romashkinskoe oilfield.

\subsection{Phylogenetic Diversity of Archaea and Bacteria in Injection and Production Water}

High-throughput sequencing of the V3-V4 region of the 16S rRNA genes was used to determine the composition of microbial communities in the samples of injection and formation water from the Arkhangelskoe and Romashkinskoe petroleum reservoirs. A total of 107,846 reads were obtained and operational taxonomic units (OTUs) were defined based on $97 \%$ identity. The $16 \mathrm{~S}$ rRNA gene 
fragments of prokaryotes of the Bacteria domain were predominant, with Proteobacteria, Actinobacteria, Firmicutes, and Bacteroidetes being the most abundant groups (Figure 1)

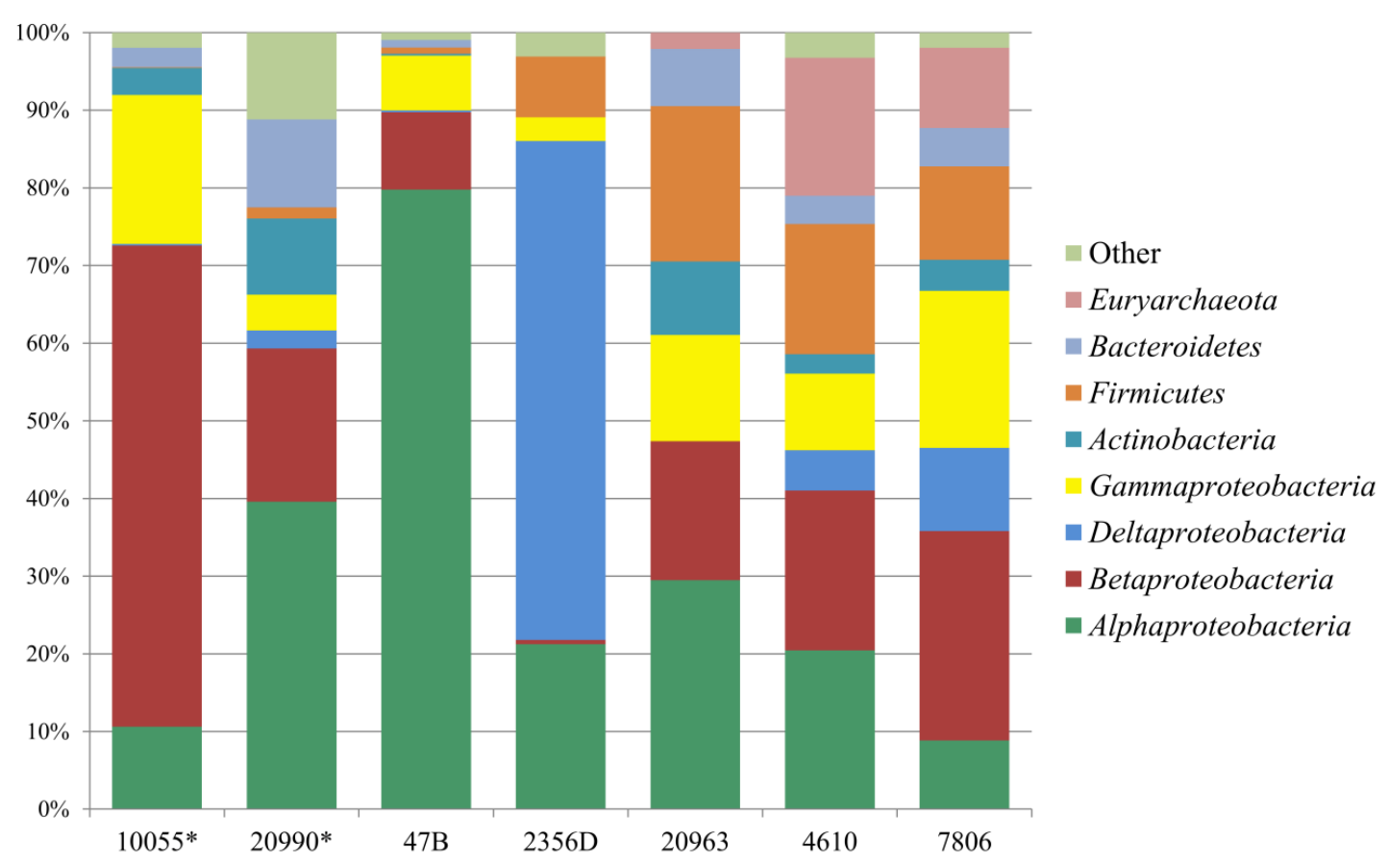

Figure 1. Taxonomic classification of archaeal and bacterial 16S rRNA gene fragments in the libraries from injection and production water samples at the phylum level (at the class level for Proteobacteria) using the RDP classifier. Injection wells are marked with *, the rest are production wells.

The sequences of Archaea were revealed in the libraries of production water from wells 4610 and 7806 of the Arkhangelskoe heavy oil reservoir, as well as in library 20963 from the Romashkinskoe oilfield, where they constituted $18.0 \%, 10.1 \%$, and $2.1 \%$ of the total number of genes in the library, respectively. Microbial communities of these reservoirs with high salinity of formation water are characterized by a noticeable occurrence of methylotrophic prokaryotes (aerobic methylotrophic bacteria and anaerobic methylotrophic methanogenic archaea).

The libraries of production water from wells 4610 and 7806 of the Arkhangelskoe heavy oil reservoir revealed the sequences of aerobic organotrophic bacteria of the genera Bacillus, Pseudomonas, Methylobacterium, of anaerobic fermentative Halanaerobium, and of syntrophic bacteria Smithella and Syntrophus, typical for water-flooded petroleum reservoirs. Sequences of less frequently occurring bacteria of the genera Herminiimonas, Acidovorax, and Sphingomonas were also detected (Figure 2).

The minor sequences belonged to fermentative bacteria of the genera Geotoga and Mesotoga and to sulfate-reducing bacteria of the genera Desulfocurvus, Desulfotignum, Desulfonatronovibrio, Desulfovibrio, Desulfosalsimonas, Desulfovermiculus, and Desulfoglaeba (PRJNA589080). Euryarchaeota sequences belonged mainly to organotrophic halophilic archaea of the genus Halomicrobium (class Halobacteria), which are capable of both aerobic and anaerobic (by nitrate reduction) growth, and to halophilic methanogenic archaea of the genus Methanohalophilus (class Methanomicrobia). The coccoid methylotrophic methanogen Methanococcoides euhalobius, capable of growth in the presence of $14 \%$ $\mathrm{NaCl}(\mathrm{wt} / \mathrm{vol})$, was originally isolated from the Bodyuzhskoe oilfield of Tatarstan [35,36]. 


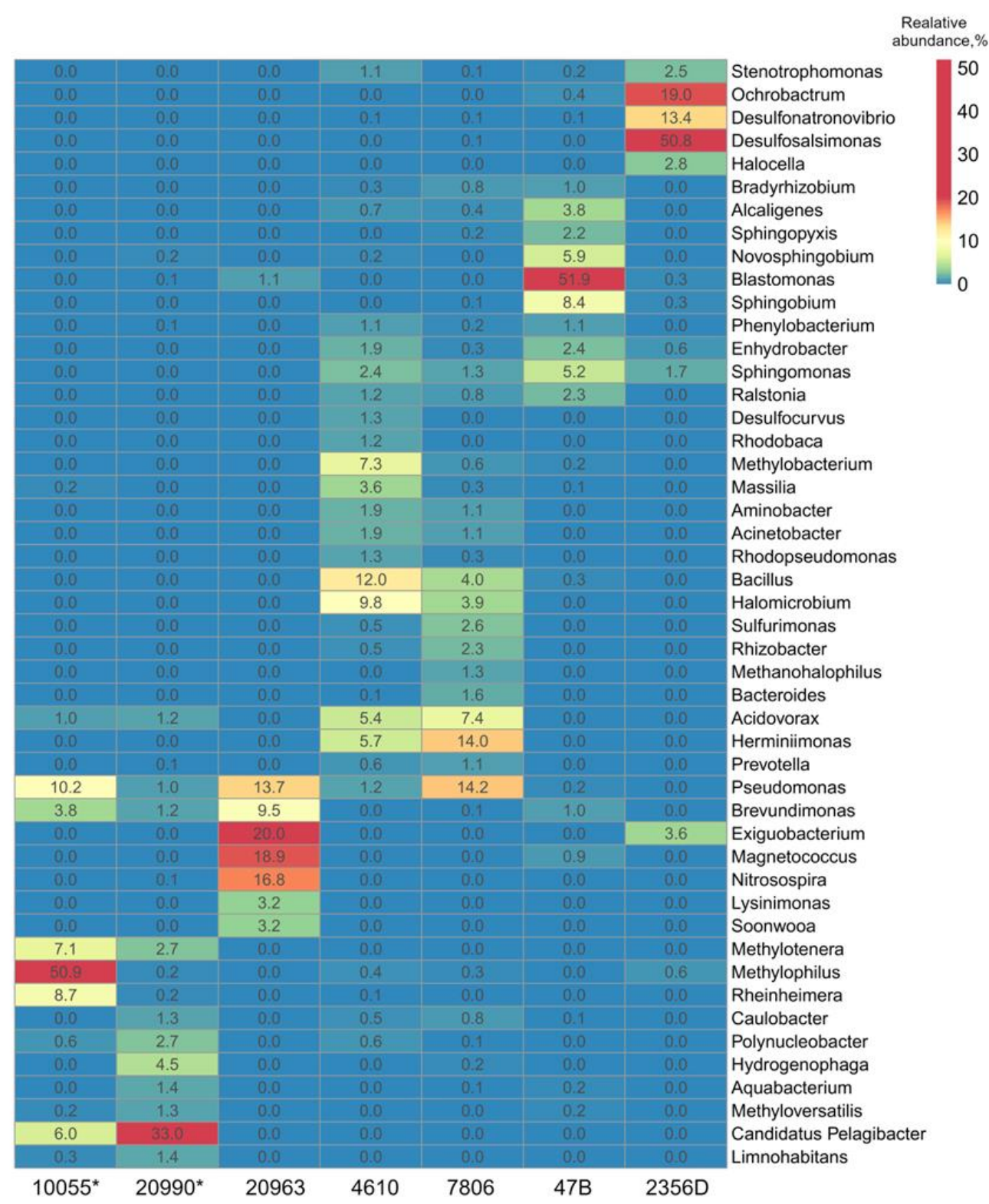

Figure 2. Heatmap analysis of the distribution of the dominant genera of Archaea and Bacteria in injection and production water samples from the Arkhangelskoe and Romashkinskoe oilfields. The relative values for microbial genera are marked by colors from blue to red, designating the least abundant to most abundant. Abundance is expressed as the ratio of the number of targeted sequences to the total number of sequences from each sample. Injection wells are marked with *, the rest are production wells.

Among bacteria revealed in the libraries of production water 20963,47B, and 2356D from the Romashkinskoe oilfield were halophilic sulfate-reducing bacteria of the genera Desulfosalsimonas and Desulfonatronovibrio, aerobic organotrophic bacteria of the genera Ochrobactrum, Pseudomonas, and Brevundimonas, as well as members of the genera Exiguobacterium, Blastomonas, Nitrosospira, which seldom occur in oilfields, and magnetotactic bacteria of the genus Magnetococcus. Members of the genus Exiguobacterium are facultatively anaerobic organotrophs [37]. Magnetococcus can grow chemolithoautotrophically with thiosulfate or sulfide as electron donors, and chemoorganoheterotrophically on acetate; thus, the conditions in the water-flooded oilfield are in agreement with their growth requirements [38]. 
In injection water $10055^{*}$, methylotrophic bacteria of the genera Methylophilus (50.9\% of the total number of genes in the library) and Methylotenera ( $7.1 \%)$ predominated, as well as members of the genera Pseudomonas (10.2\%), Rheinheimera (8.7\%), and 'Candidatus Pelagibacter' (6\%). In injection water 20990*, bacteria of the genera 'Candidatus Pelagibacter' (33\%), Hydrogenophaga (4.5\%), Methylotenera (2.7\%), and Polynucleobacter (2.7\%) were found. Aerobic chemoorganotrophic bacteria of the genus Polynucleobacter, which utilize a narrow range of substrates (acetate, pyruvate, malate, etc.) under aerobic conditions or grow as facultative anaerobes, are known to be common in freshwater environments [39]. The chemoheterotrophic marine bacteria of the SAR11 clade Candidatus Pelagibacter, which were revealed in both samples of injection water, are "the Earth's most abundant organisms" [40]. The reason for the occurrence of these bacteria far from marine habitats remains unclear.

Application of the principle component analysis (PCA) method revealed considerable similarity in the composition of microbial communities in production water samples from the same petroleum reservoirs (Figure 3). The 4610 and 7806 communities from Arkhangelskoe oilfield, where formation water contained high concentrations of sulfate, a diverse archaeal population, and sulfate-reducing bacteria as minor phylotypes, formed a separate group. Another separate group was represented by communities of production water from the Romashkinskoe oilfield (47B, 2356D, and 20963), where sulfate concentration in the water was low and various halotolerant aerobic organotrophic bacteria and halophilic sulfate reducers were present. Microorganisms of injection water communities formed two groups, which were different from formation water communities.

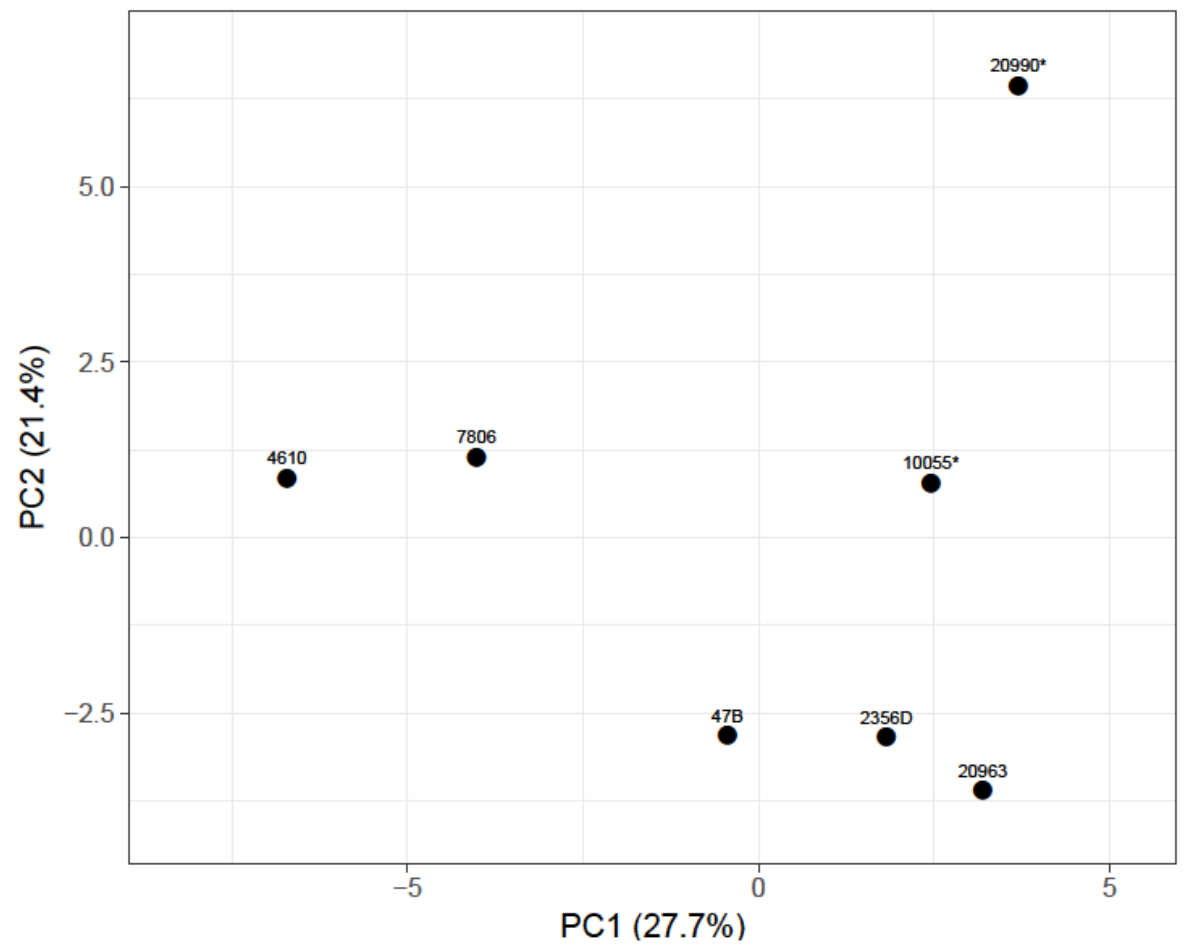

Figure 3. Principal component analysis (PCA) based on relative abundance of $16 \mathrm{~S}$ rRNA gene operational taxonomic units (OTUs) from injection and production water samples of the Arkhangelskoe and Romashkinskoe oilfields.

Earlier analysis of the $16 \mathrm{~S}$ rRNA genes of the microbial community from injection water $5600^{*}$ of the Cheremukhovskoe oilfield revealed bacteria of the genera Dechloromonas (15\%), Phenylobacterium (12\%), hydrocarbon-oxidizing bacteria of the genera Acinetobacter (5\%) and Rhodococcus (1.2\%), and of sulfateand sulfur-reducing bacteria of the genera Desulfovibrio, Desulfomicrobium, and Desulfuromonas [23]. Denaturing gradient gel electrophoresis (DGGE) analysis of the $m c r A$ genes in injection water $5600^{*}$ revealed methanogens of the genera Methanospirillum, Methanobacterium, and Methanoregula; production 
water from sample 5464 revealed methanogens of the genera Methanosarcina, Methanoculleus, and unidentified Thermoplasmata. These results indicate that both microorganisms from the surface freshwater basins and the reservoir microbiota adapted to oilfield conditions are delivered into the oil reservoir with injection water (a mixture of surface fresh water and formation water after oil removal).

\subsection{Production of Oil-Releasing Compounds by Bacteria from Heavy Oil Reservoirs}

\subsubsection{Aerobic Bacteria Producing Biosurfactants}

A number of aerobic organotrophic bacteria from the genera Rhodococcus, Gordonia, Nocardia, Pseudomonas, Bacillus, Salinicola, Chromohalobacter, and Cellulomonas were previously isolated from Russian heavy oil reservoirs [23]. These bacteria produced biosurfactants in the media with a variety of organic substrates (acetate, glucose, sucrose, ethanol, peptone, and glycerol), as well as in the medium with crude oil.

The strains Gordonia amicalis 6-1 and Rhodococcus erythropolis HO-KS22, which exhibited the most pronounced decrease in the surface tension, were studied in more detail. R. erythropolis HO-KS22 grew aerobically within broad ranges of salinity $\left(0 \mathrm{~g} \cdot \mathrm{L}^{-1}\right.$ to $80 \mathrm{~g} \cdot \mathrm{L}^{-1} \mathrm{NaCl}$, optimum at $\left.10 \mathrm{~g} \cdot \mathrm{L}^{-1}\right), \mathrm{pH}(5.5-9.5$, optimum at $\mathrm{pH} 7.0-7.5)$, and temperature $\left(5-37^{\circ} \mathrm{C}\right.$, optimum at $\left.28^{\circ} \mathrm{C}\right)$. G. amicalis $6-1$ grew aerobically at $0 \mathrm{~g} \cdot \mathrm{L}^{-1}$ to $100 \mathrm{~g} \cdot \mathrm{L}^{-1} \mathrm{NaCl}$ (optimum at $15 \mathrm{~g} \cdot \mathrm{L}^{-1}$ ), $\mathrm{pH}$ from 6.5 to 8.2 (optimum at 7.4 ), and at $5{ }^{\circ} \mathrm{C}$ to $45^{\circ} \mathrm{C}$ (optimum at $28^{\circ} \mathrm{C}$ ). Biodegradation of heavy oil by G. amicalis 6-1 resulted in the utilization of $\mathrm{C}_{11}, \mathrm{C}_{12}, \mathrm{C}_{13}, \mathrm{C}_{15-\mathrm{C} 21}$, and $\mathrm{C}_{23}$ n-alkanes (Figure A2a,b). After seven days of incubation, R. erythropolis HO-KS22 consumed most of the $n$-alkanes from heavy oil (Figure A2c). In the medium with crude oil, the strains G. amicalis 6-1 and R. erythropolis HO-KS22 decreased the interfacial tension from $21 \mathrm{mN} / \mathrm{m}$ to $0.2-1.0 \mathrm{mN} / \mathrm{m}$. In the medium with glucose, G. amicalis 6-1 synthesized biosurfactants during the highest biomass accumulation (late logarithmic to early stationary growth phases), as was evident from the decrease in surface tension from $72 \mathrm{mN} / \mathrm{m}$ to $20 \mathrm{mN} / \mathrm{m}$ and of the interfacial tension against n-hexadecane from $47 \mathrm{mN} / \mathrm{m}$ to $1-2.1 \mathrm{mN} / \mathrm{m}$ (Figure A3a-c). The most pronounced decrease in surface tension was observed at the glucose/nitrate ratio of $5 / 0.5(\mathrm{~g} / \mathrm{g}$ per $1 \mathrm{~L})$; the highest decrease in interfacial tension occurred at the 20/1.0 ratio (g/g). Salinity and temperature optima of G. amicalis 6-1 and $R$. erythropolis HO-KS22 and the ability to consume crude oil indicate their adaptation to the conditions of the near bottom zone of injection wells, where dissolved oxygen is supplied by injected water; these physiological characteristics may be used in the application of strains 6-1 and HO-KS22 for injection into oilfields in order to increase oil recovery or to remove asphaltene-resin-paraffin deposits.

The microorganisms capable of decreasing surface tension by more than $10 \mathrm{mN} / \mathrm{m}$ are considered potential biosurfactant producers [41]. The isolation of biosurfactants from the media and investigation of their structure were beyond the scope of the present work. The surface tension decrease of the media caused by the isolates G. amicalis 6-1 and R. erythropolis HO-KS22 was compared to that caused by sulfonol, an anionic synthetic surfactant used in the oil industry for oil recovery enhancement. The biosurfactants present in liquid cultures of the strains decreased the surface tension to the same degree as a sulfonol solution at $1.3 \mathrm{~g} \mathrm{~L}^{-1}$. Thus, G. amicalis 6-1 and R. erythropolis HO-KS22 are promising for application in the biotechnologies for enhanced oil recovery and for oil removal from contaminated environments. G. amicalis 6-1, which is also able to use dibenzothiophene as a sulfur source in the presence of other organic substrates, was patented [42].

\subsubsection{Fermentative Bacteria Producing Low Fatty Acids and Alcohols}

While the population of anaerobic fermentative bacteria was the most numerous one in formation water samples (Figure A1), their growth on heavy oil was very poor (data not shown). The growth of fermentative enrichments in media with peptone and glucose did not result in surface tension changes. The studied fermentative enrichment 7SA and pure culture Oscillibacter ruminantium strain AIK fermented organic substrates with the production of low fatty acids, alcohols, and gases $\left(\mathrm{H}_{2}\right.$ and $\mathrm{CO}_{2}$ ). The 7SA fermentative enrichment produced low fatty acids (acetic, $50.0 \mathrm{mg} \cdot \mathrm{L}^{-1}$; propionic, $190.0 \mathrm{mg} \cdot \mathrm{L}^{-1}$; and $n$-butyric, $3590.0 \mathrm{mg} \cdot \mathrm{L}^{-1}$ ), the $\mathrm{pH}$ of the medium decreased from 7.0 to 5.5 . O. 
ruminantium AIK produced low fatty acids (LFA) (acetic, $1895.0 \mathrm{mg} \cdot \mathrm{L}^{-1}$; propionic, $390.0 \mathrm{mg} \cdot \mathrm{L}^{-1}$; isobutyric, $370.0 \mathrm{mg} \cdot \mathrm{L}^{-1}$; $n$-butyric, $3830.0 \mathrm{mg} \cdot \mathrm{L}^{-1}$; and other LFA, $\left.790.0 \mathrm{~g} \cdot \mathrm{L}^{-1}\right)$, isopropanol, $110.0 \mathrm{~g} \cdot \mathrm{L}^{-1}$; and gases $\left(\mathrm{H}_{2}\right.$ and $\left.\mathrm{CO}_{2}\right) ; \mathrm{pH}$ decreased to 4.5. Volatile fatty acids are known to promote the dissolution of carbonate oil-bearing rocks and to increase their porosity, permeability, and oil recovery.

Methanogens were detected in a number of samples by molecular, cultural, and radiotracer techniques. It is, however, hardly probable that fermentative bacteria may provide enough substrates for methanogens for methane to have a significant effect on oil displacement, even in the presence of sugar-containing substrates. The cultures of aerobic bacteria and anaerobic fermentative bacteria were therefore used in core flooding experiments.

\subsection{Core Flooding for Heavy Oil Recovery}

The cultures of biosurfactant-producing aerobic bacteria and of fermentative bacteria-producing volatile acids and alcohols were grown in liquid media with sugar-containing substrates and then injected into the models. In these experiments only the effect of introduced liquid cultures of aerobic and anaerobic bacteria on heavy oil recovery was estimated. The distribution of bacteria in the pore space of the models and bacterial growth in time were not analyzed.

The oilfield models were prepared using the natural carbonate cores from oilfields and were saturated with heavy oil (density $0.93 \mathrm{~g} / \mathrm{cm}^{3}$ ). The cores were then flooded with $\mathrm{NaCl}$ solution $\left(30 \mathrm{~g} \cdot \mathrm{L}^{-1}\right)$, which was similar to formation water salinity, to $100 \%$ water content in the outflowing liquid. After primary oil displacement with the $\mathrm{NaCl}$ solution, the residual oil saturation of the cores varied from $67.3 \%$ to $80 \%$, indicating that most of the water present in the column was replaced by oil. The results obtained with the carbonate cores are shown in Table 2.

Secondary core flooding with $10 \mathrm{PV}$ of the liquid cultures of aerobic and anaerobic bacteria resulted in decreased residual oil saturation in the cores and additional oil displacement after MEOR. Injection of the liquid culture O. ruminantium AIK, which contained low fatty acids $\left(7.27 \mathrm{~g} \cdot \mathrm{L}^{-1}\right)$, isopropanol, and the biomass, was accompanied by additional displacement of $30.5 \%$ and $60.4 \%$ of oil $(45.5 \%$ on average) from cores \#1 and \#2. Additional oil recovery from cores \#3 and \#4 flooded with fermentative enrichment 7SA was $11.6 \%$ and $15.3 \%$ (13.4\% on average), which was probably the result of lower concentrations of the fermentation products in the culture 7SA $\left(3.83 \mathrm{~g} \mathrm{LFA} \mathrm{L}^{-1}\right)$.

The flooding of cores \#5 and \#6 with the aerobic culture R. erythropolis HO-KS22 resulted in the highest additional oil displacement of $60.6 \%$ and $46.4 \%$ (53.5\% on average) (Figure 4 ).

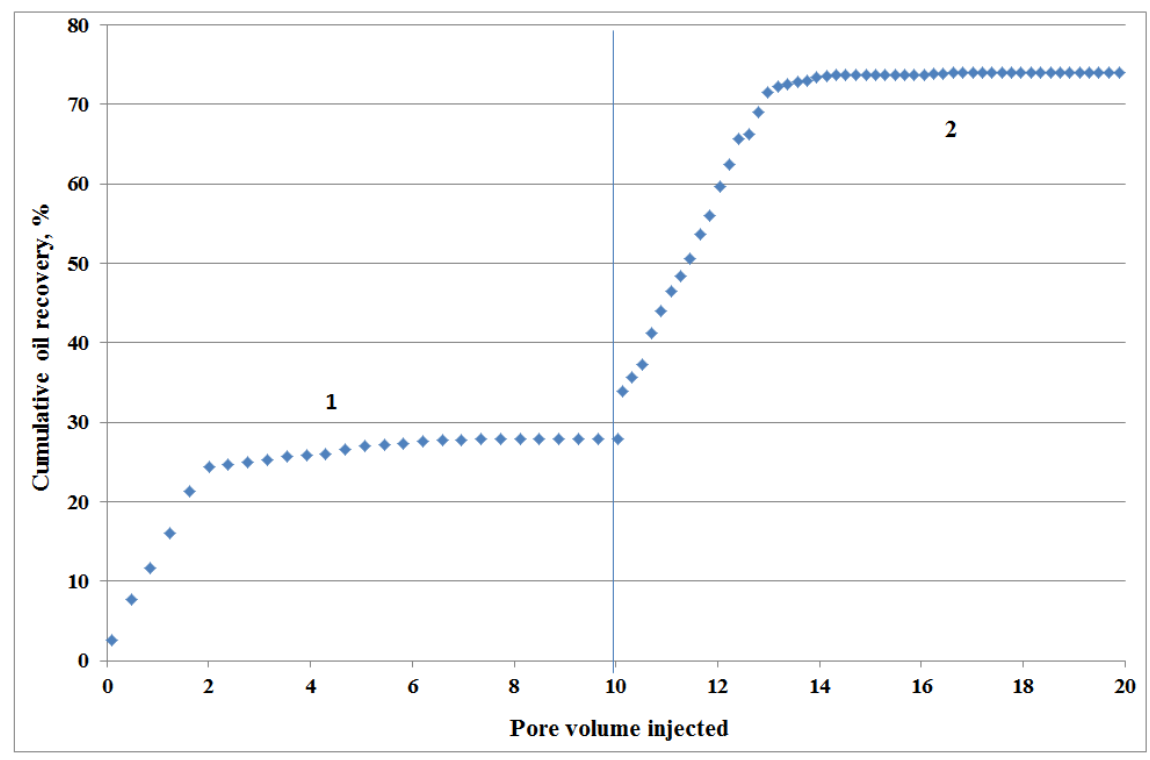

Figure 4. Cumulative oil recovered from the core by successive injection of water with a density of $1.04 \mathrm{~g} \cdot \mathrm{cm}^{-3}(1)$ and liquid culture of R. erythropolis HO-KS22 (2). Rate of injection was $1 \mathrm{~mL} \cdot \mathrm{min}^{-1}$. 
Table 2. Core properties and heavy oil recovery as a result of flooding of aerobic and anaerobic cultures.

\begin{tabular}{|c|c|c|c|c|c|c|c|c|c|c|c|c|}
\hline \multirow{2}{*}{ Parameters } & \multicolumn{12}{|c|}{ Experiments } \\
\hline & $\# 1$ & $\# 2$ & Average & $\# 3$ & $\# 4$ & Average & \# 5 & $\# 6$ & Average & $\# 7$ & $\# 8$ & Average \\
\hline Pore volume, $\mathrm{cm}^{3}$ & 8.14 & 8.53 & 8.34 & 9.0 & 9.5 & 9.25 & 10.46 & 10.12 & 10.29 & 8.13 & 13.3 & 10.7 \\
\hline $\begin{array}{l}\text { Absolute permeability, } \\
10^{-3} \times \mu \mathrm{m}^{2}\end{array}$ & 254 & 372 & 313 & 331 & 220 & 276 & 333 & 324 & 328.5 & 379 & 289 & 334 \\
\hline $\begin{array}{l}\text { Connate water } \\
\text { saturation, fraction }\end{array}$ & 0.251 & 0.235 & 0.243 & 0.28 & 0.27 & 0.27 & 0.204 & 0.200 & 0.202 & 0.26 & 0.23 & 0.25 \\
\hline \multicolumn{13}{|c|}{ Primary oil displacement with the $\mathrm{NaCl}$ solution $\left(30 \mathrm{~g} \mathrm{~L}^{-1}\right)$} \\
\hline Pore volume injected, PV & 10 & 10 & 10 & 10 & 10 & 10 & 10 & 10 & 10 & 10 & 10 & 10 \\
\hline $\begin{array}{l}\text { Residual oil saturation } \\
\text { before MEOR, } \%\end{array}$ & 67.3 & 77.6 & 72.4 & 79.5 & 68.6 & 74.0 & 74.6 & 72.1 & 73.3 & 80.0 & 69.3 & 74.6 \\
\hline \multicolumn{13}{|c|}{ Additional oil displacement by grown culture in the liquid medium } \\
\hline Culture & \multicolumn{3}{|c|}{ O. ruminantium AIK } & \multicolumn{3}{|c|}{ Fermentative enrichment 7SA } & \multicolumn{3}{|c|}{ R. erythropolis HO-KS22 } & \multicolumn{3}{|c|}{ R. erythropolis HO-KS22 + G. amicalis 6-1 } \\
\hline $\begin{array}{l}\text { Residual oil saturation } \\
\text { after MEOR, \% }\end{array}$ & 36.6 & 17.2 & 26.9 & 67.9 & 53.3 & 60.6 & 14.0 & 25.7 & 19.8 & 25.8 & 37.5 & 31.6 \\
\hline $\begin{array}{c}\text { Heavy oil recovery } \\
\text { enhancement as a result } \\
\text { of MEOR, \% }\end{array}$ & 30.7 & 60.4 & 45.5 & 11.6 & 15.3 & 13.4 & 60.6 & 46.4 & 53.5 & 54.2 & 31.8 & 43.0 \\
\hline
\end{tabular}


The flooding of cores \#7 and \#8 with liquid cultures of strains HO-KS22 and 6-1 in the 1:1 ratio ( $\mathrm{vol} / \mathrm{vol})$ caused additional oil replacement of $54.2 \%$ and $31.8 \%$ ( $43.0 \%$ on average). The increase in oil recovery observed in core-flooding experiments \#5-\#8 was probably due to the ability of the aerobic Rhodococcus and Gordonia isolates to produce biosurfactants, both associated with their cell walls and released into the medium. Biosurfactants are known to be bipolar molecules concentrating at the oil-water interface and causing oil emulsification and a decrease in the interfacial tension between oil and water.

Additional oil displacement in experiments with fermentative cultures was probably caused by the dissolution of carbonate rocks and by their porosity increasing due to the action of the fermentation products (primarily acetic and butyric acids and $\mathrm{CO}_{2}$ ). Short-chain fatty acids interacted with the carbonate matrix according to the following equations:

$$
\begin{gathered}
2 \mathrm{CH}_{3} \mathrm{COOH}+\mathrm{CaCO}_{3} \rightarrow\left(\mathrm{CH}_{3} \mathrm{COO}\right)_{2} \mathrm{Ca}+\mathrm{H}_{2} \mathrm{CO}_{3} ; \\
2 \mathrm{CH}_{3} \mathrm{CH}_{2} \mathrm{CH}_{2} \mathrm{COOH}+\mathrm{CaCO}_{3} \rightarrow\left(\mathrm{CH}_{3} \mathrm{CH}_{2} \mathrm{CH}_{2} \mathrm{COO}\right)_{2} \mathrm{Ca}+\mathrm{H}_{2} \mathrm{CO}_{3} .
\end{gathered}
$$

As a result, soluble salts were produced and rock permeability in the contact zone increased, while calcium and magnesium salts of fatty acids with over seven atoms in their carbon chain are insoluble, so their accumulation resulted in decreased permeability. In the collectors consisting of aragonite and calcite, increased carbonate concentration in the medium may initiate the process of dolomitization, with magnesium incorporating into the structure of carbonates. The dolomite thus formed has lower volume than calcite or aragonite, and this process should in theory increase the rock permeability [43]. Inflow of the biomass of aerobic and anaerobic bacteria was accompanied by sealing of the highly permeable interlayers, which resulted in the changed phase permeability of the models (data not shown). The interaction of microbial metabolites with the rock, oil, and water resulted in more widespread water flooding and increased oil recovery. The results of model experiments were confirmed in the course of pilot trials at heavy oil reservoirs.

\subsection{Pilot Trials of MEOR Biotechnology at Petroleum Reservoirs}

As a substrate for microbial growth, heavy oil, being by its nature a product of biodegradation, is therefore a poor source of the easily utilized fractions most available to microorganisms. It may be expected, however, that in the presence of oxidants, the oilfield microbial community will oxidize oil with the production of a spectrum of oil-displacing metabolites. A field pilot experiment for enhancing oil recovery using the microbiological method was carried out at the Cheremukhovskoe oilfield, in the zone of the injection well 5600. The Cheremukhovskoe oilfield, containing heavy oil with a density of $0.932 \mathrm{~kg} / \mathrm{m}^{3}$, has been exploited since 1997. Water-flooding with fresh river water mixed with production water separated from oil was initiated in 2001. The initial recoverable reserves were $802 \times 10^{3} \mathrm{t}$. The average oil saturation was $0.810 \mathrm{U}$. The average water cut of oil production is presently $51 \%$. The same experiment was carried out in the zone of the injection well 1010 at the Vostochno-Anzirskoe oilfield with oil with a lower density of $0.856 \mathrm{~kg} / \mathrm{m}^{3}$. Since 2003, the Vostochno-Anzirskoe oilfield has been exploited with focal water injection in order to preserve the seam pressure. The initial recoverable reserves were $582 \times 10^{3} \mathrm{t}$. The average oil saturation was $0.713 \mathrm{U}$.

The biotechnological treatment at the Cheremukhovskoe and Vostochno-Anzirskoe oilfields included the injection of oil-oxidizing bacteria adapted to oilfield conditions into the reservoir through injection wells. For the sustainable growth of oil-oxidizing bacteria, oxygen (as a $\mathrm{H}_{2} \mathrm{O}_{2}$ solution) and $\left(\mathrm{NH}_{4}\right)_{2} \mathrm{HPO}_{4}$ solution as a source of biogenic elements were injected in order to initiate the first stage of the oxidation of oil hydrocarbons. After the treatment of injection wells 5600 and 1010, the cultured microorganisms and the rates of microbial processes in the zone of production wells were studied and the effect of microorganisms on oil recovery was assessed. Unfortunately, we had no possibility of monitoring the changes in the microbial community during the pilot trials by molecular techniques. 
The water in wells 5454 and 5463 of the Cheremukhovskoe oilfield showed the highest oil displacement, the highest numbers of aerobic organotrophic bacteria (including hydrocarbon oxidizers), and anaerobic fermentative bacteria were found to increase. The numbers of hydrogenotrophic and acetate-utilizing methanogens did not change in the course of the biotechnological treatment, although radiotracer analysis revealed a 1.5-4.5-fold increase in methanogenesis rates in a number of production wells (Table 3). In sulfate-containing formation water, sulfate reduction is unavoidable, unless special measures for its suppression are taken. Sulfate reduction rate in the zone of responding wells increased from 4-98 $\mathrm{ng} \mathrm{S}^{2-} \cdot \mathrm{L}^{-1} \cdot \mathrm{day}^{-1}$ (during the baseline period) to $13-213 \mathrm{ng} \mathrm{S}^{2-} \cdot \mathrm{L}^{-1} \cdot \mathrm{day}^{-1}$ in the course of the trial. Heavy oil biodegradation was accompanied by increased concentrations of acetate (from $1.3-3.0 \mathrm{mg} \cdot \mathrm{L}^{-1}$ to $20-30 \mathrm{mg} \cdot \mathrm{L}^{-1}$ ) and bicarbonate (from $244-305 \mathrm{mg} \cdot \mathrm{L}^{-1}$ to $476-671 \mathrm{mg} \cdot \mathrm{L}^{-1}$ ) in the formation water of responding wells. In the course of the experiment, microbial metabolites spread from the near bottom zone of the injection well and affected oil displacement 5-7 months after the introduction of bacteria, the oxidant, and the nitrogen and phosphorus salt in the reservoir (Figure 5). As a result of the pilot trial at the Cheremukhovskoe oilfield, $1141 \mathrm{t}$ of oil was additionally recovered in the course of a year after the onset of the treatment. Although the abundance of hydrocarbon-oxidizing and fermentative bacteria, as well as bicarbonate concentration, increased the zone of production well 5464, this did not result in enhanced oil recovery, probably due to the high salinity of formation water in this area (over $186 \mathrm{~g} \cdot \mathrm{L}^{-1}$ ), which prevented microbial growth and the formation of oil-releasing metabolites.

At the Vostochno-Anzirskoe oilfield, the biotechnological treatment resulted in a very low increase in oil recovery. A total of $1250 \mathrm{t}$ of oil was obtained in the course of two pilot trials. The efficiency of the biotechnological treatment was confirmed by the water content in the production of the responding wells decreasing by $18-35 \%$ (Figure 5 ).

In the MEOR pilot trials at the heavy oil reservoirs, both at the high-temperature Dagang oilfield (China) [18-20] and at the low-temperature Cheremukhovskoe and Romashkinskoe oilfields [44,45] (Russia), oil recovery became more sustainable after the biotechnological treatment, which had a positive effect of total oil recovery. The Cheremukhovskoe oilfield is characterized by a low reservoir temperature $\left(20.2-21.3^{\circ} \mathrm{C}\right)$. The efficiency of carbonate dissolution by acetate at a low temperature was estimated in laboratory experiments [46]. It was shown that the dissolution of calcium carbonate in aqueous solutions of acetic acid occurs even at $10^{\circ} \mathrm{C}$. At the low-temperature $\left(17-23^{\circ} \mathrm{C}\right)$ bed 302 with carbonate collector and heavy oil at the Romashkinskoe oilfield, an MEOR pilot trial was performed based on the introduction of Clostridium tyrobutyricum and molasses into the oil stratum [44,45]. Monitoring the concentrations of fatty acids, calcium, and carbonates dissolved in the formation water of bed 302 provided direct evidence of carbonate dissolution by acidic products of microbial metabolism. According to the van't Hoff equation, the rate of this reaction would have certainly been higher at higher temperatures. The dissolution rate of carbonate rock is probably less important than the fact of formation of low fatty acids directly in the pore water, where their effect on the oil-bearing rocks is maximal.

Due to the multistage and interrelated nature of microbial processes occurring in oilfields, it is difficult to attribute enhanced oil recovery to a single mechanism. Field experiments at heavy oil reservoirs indicated that all groups of microbial metabolites produced during molasses fermentation [44,45] and oil oxidation [18-20] affected oil displacement. Volatile fatty acids dissolved the carbonate rocks, increasing their porosity and permeability. The gases produced in the course of transformation of the fermentation products in the microbial trophic chain $\left(\mathrm{CO}_{2}\right.$, hydrogen, and methane) caused local restoration of the seam pressure, increased gas factor, oil swelling, and decreased oil viscosity, as well as increased collector permeability due to carbonate dissolution by $\mathrm{CO}_{2}$. The surfactants caused a decrease in the interfacial tension at the oil-water and oil-rock boundaries and to oil emulsification. Both microbial exometabolites and the biomass itself affected the motility of formation fluids and the direction of hydrodynamic flows in the oilfield, also increasing the waterflooding coverage. 
Table 3. Microbial numbers, acetate, $\mathrm{HCO}_{3}{ }^{-}$, and $\mathrm{SO}_{4}{ }^{2-}$ concentrations and rates of sulfate reduction and methanogenesis in production water before biotechnological treatment (1) and 10 months after the treatment (2).

\begin{tabular}{|c|c|c|c|c|c|c|c|c|c|c|c|c|c|}
\hline \multirow{2}{*}{$\begin{array}{l}\text { Oilfield, } \\
\text { Well No. }\end{array}$} & \multirow{2}{*}{$\begin{array}{c}\text { Time of } \\
\text { Analysis }\end{array}$} & \multicolumn{3}{|c|}{ Microbial Numbers, cells $\cdot \mathrm{mL}^{-1}$} & \multicolumn{3}{|c|}{ Concentration, $\mathrm{mg} \cdot \mathrm{L}^{-1}$} & \multicolumn{3}{|c|}{$\begin{array}{c}\text { Methanogenesis Rate, } \mathrm{nl} \\
\mathrm{CH}_{4} \cdot \mathrm{L}^{-1} \cdot \mathrm{day}^{-1} \text { from }\end{array}$} & \multirow{2}{*}{$\begin{array}{l}\% \text { from } \\
\text { Acetate }\end{array}$} & \multirow{2}{*}{ 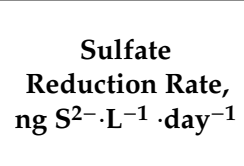 } & \multirow{2}{*}{$\begin{array}{l}\text { Additional } \\
\text { Oil, } \mathrm{t}\end{array}$} \\
\hline & & Aerobes & Fermenters & $\begin{array}{c}\text { Sulfate } \\
\text { Reducers }\end{array}$ & $\mathrm{HCO}_{3}^{-}$ & Acetate & $\mathrm{SO}_{4}{ }^{2-}$ & $\mathrm{HCO}_{3}{ }^{-}$ & Acetate & Total & & & \\
\hline \multicolumn{14}{|c|}{ Cheremukhovskoe oilfield } \\
\hline $5600^{*}$ & 1 & $10^{6}$ & $10^{6}$ & $\mathrm{Nd}$ & 244 & $\mathrm{Nd}$ & 74 & & & & & & \\
\hline \multirow{2}{*}{5452} & 1 & $10^{2}$ & $10^{6}$ & $10^{3}$ & 6 & 2.1 & 96 & 4 & 44 & 48 & 92 & 4 & \\
\hline & 2 & $10^{3}$ & $10^{3}$ & $10^{4}$ & 641 & 20.6 & 96 & 86 & 127 & 213 & 60 & 13 & 72 \\
\hline \multirow{2}{*}{5454} & 1 & 10 & $10^{5}$ & $10^{2}$ & 305 & 2.6 & 80 & 26 & 24 & 50 & 47 & 91 & \\
\hline & 2 & $10^{4}$ & $10^{5}$ & $\leq 10$ & 671 & 30.4 & 80 & 31 & 45 & 76 & 59 & 164 & 599 \\
\hline \multirow{2}{*}{5463} & 1 & 0 & $10^{2}$ & 0 & 305 & 3.0 & 143 & 78 & 17 & 95 & 18 & 98 & \\
\hline & 2 & $\leq 10$ & $10^{4}$ & 10 & 165 & 26.0 & 143 & 82 & 311 & 393 & 79 & 213 & 507 \\
\hline \multirow{2}{*}{5464} & 1 & 0 & $10^{2}$ & $\leq 10$ & 244 & 1.3 & 218 & 70 & 47 & 117 & 40 & 108 & \\
\hline & 2 & $\leq 10$ & $10^{5}$ & 0 & 476 & 1.4 & 218 & 65 & 12 & 77 & 16 & 96 & -37 \\
\hline \multicolumn{14}{|c|}{ Vostochno-Anzirskoe oilfield } \\
\hline $1010^{*}$ & 1 & $10^{6}$ & $10^{4}$ & $\mathrm{Nd}$ & 293 & $\mathrm{Nd}$ & 732 & & & & & & \\
\hline \multirow{2}{*}{ 245D } & 1 & $10^{2}$ & $10^{3}$ & $10^{2}$ & 171 & 1.2 & 147 & 90 & 0 & 90 & 0 & 198 & \\
\hline & 2 & 0 & $10^{6}$ & $10^{4}$ & 342 & 2.3 & 147 & 31 & 26 & 57 & 46 & 65 & -4 \\
\hline 1012 & 2 & $\mathrm{Nd}$ & $\mathrm{Nd}$ & $\mathrm{Nd}$ & 756 & 9.8 & 147 & 28 & 53 & 81 & 65 & 137 & 42 \\
\hline 1009 & 2 & & & & & & & & & & & & 71 \\
\hline
\end{tabular}

* Injection well, other wells are production wells. Nd means no data. 

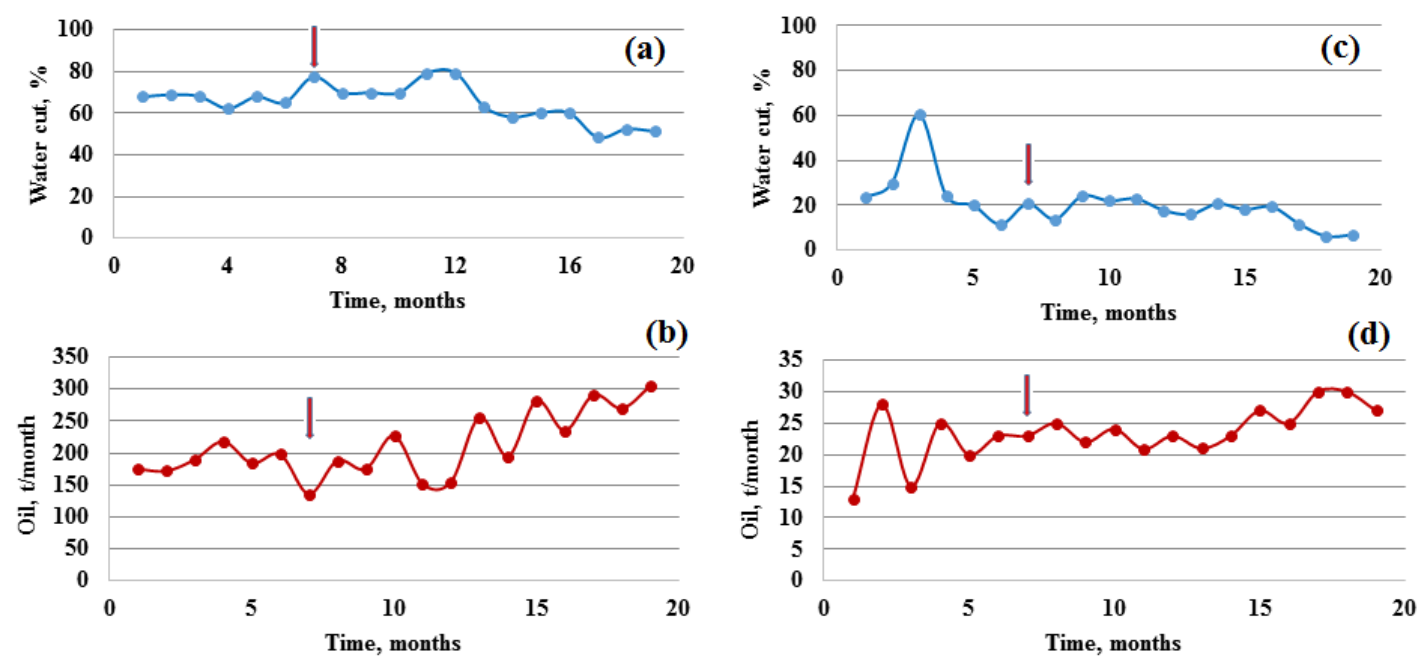

Figure 5. Water cut $(\%, \mathbf{a}, \mathbf{c})$ and oil recovery $(\mathrm{t} / \mathrm{month}, \mathbf{b}, \mathbf{d})$ from production wells $5463(\mathbf{a}, \mathbf{b})$ and 1009 (c,d) during the baseline period and during the biotechnology trial at the Cheremukhovskoe and the Vostochno-Anzirskoe oilfields, respectively. The arrow designates the beginning of the biotechnological treatment.

\section{Conclusions}

Our results indicate that the studied low-temperature water-flooded heavy oil reservoirs (Russia) contain microbial populations capable of producing oil-displacing metabolites.

Aerobic bacteria Rhodococcus erythropolis HO-KS22 and Gordonia amicalis 6-1 isolated from oil reservoirs were capable of oxidizing heavy crude oil, and produce biosurfactants which significantly decrease the surface and interfacial tension of the media. G. amicalis 6-1 and R. erythropolis HO-KS22 have potential for applications in paraffin control, microbial enhanced oil recovery (MEOR), and the bioremediation of hydrocarbon-polluted environments.

The aerobic microbial community of heavy oil reservoirs was poor. Thus, its enrichment (bioaugmentation) with hydrocarbon-oxidizing bacteria adapted to oilfield conditions is a prerequisite for application of the MEOR technologies based on oil oxidation.

Fermentative bacteria from heavy oil reservoirs did not grow on oil; however, they produced volatile fatty acids, alcohols, and gases $\left(\mathrm{H}_{2}\right.$ and $\left.\mathrm{CO}_{2}\right)$ when growing on sugar-containing substrates.

In core-flooding tests, liquid cultures of aerobic bacteria-producing biosurfactants were more effective in heavy oil displacement than fermentative bacteria-producing low fatty acids, alcohols, and gas, which resulted in a recovery of $43.0-53.5 \%$ and $13.4-45.5 \%$ of additional oil.

The pilot trial at the Cheremukhovskoe oilfield confirmed the efficiency of the MEOR technology based on the introduction of hydrocarbon-oxidizing bacteria together with injection of the oxidant as an $\mathrm{H}_{2} \mathrm{O}_{2}$ solution and of $\left(\mathrm{NH}_{4}\right)_{2} \mathrm{HPO}_{4}$ as a nitrogen and phosphorous source for low-temperature heavy oil reservoirs.

\section{Patents}

Borzenkov, I.A.; Sokolova D.S.; Nazina, T.N.; Babich, T.L.; Semenova, E.M.; Ershov, A.P.; Khisametdinov, M.R. Gordonia amicalis strain with ability of generation directly in oil reservoir of oil-displacing agent-bioPAV and decreasing content of organosulfur compounds of oil. Patent RU No. 2,673,747 C1. Published: 29.11.2018. (In Russian). http://www1.fips.ru/fips_serv1/fips_servlet? $\mathrm{DB}=$ RUPAT $\&$ DocNumber $=2673747 \&$ TypeFile $=\mathrm{html}$ 
Author Contributions: Conceptualization, T.N. and I.B.; Data curation, D.S. (Dmitriy Serdukov) and M.K.; Formal analysis, D.S. (Diyana Sokolova), D.G. and M.K.; Investigation, D.S. (Diyana Sokolova), D.G., E.S., T.B., S.B., D.S. (Dmitriy Serdukov), A.E., M.K. and I.B.; Methodology, M.K.; Project administration, T.N., D.V., K.B. and I.B.; Resources, D.V. and K.B.; Supervision, T.N.; Writing—original draft, T.N., D.S. (Diyana Sokolova), D.G., E.S., M.K. and I.B.; Writing-review and editing, T.N. All of the authors read and approved the submitted manuscript.

Funding: Molecular and physicochemical studies of petroleum reservoirs and laboratory physical modeling of oil recovery were supported by the Russian Science Foundation (grant no. 16-14-00028). Physiology of isolated bacteria was studies under support of the Ministry of Science and Higher Education of the Russian Federation. The pilot trials were performed under support of the RITEK Co.

Acknowledgments: We are grateful to V.I. Darishchev (the Ritek Co.) and A.T. Zaripov (TatNIPIneft) for the administrative support at the oilfields.

Conflicts of Interest: The authors declare no conflict of interest.

\section{Appendix A}

Table A1. Characteristics of the studied petroleum reservoirs.

\begin{tabular}{|c|c|c|c|c|}
\hline Parameters & $\begin{array}{c}\text { Cheremukhovskoe } \\
\text { Oilfield }\end{array}$ & $\begin{array}{c}\text { Arkhangelskoe } \\
\text { Oilfield }\end{array}$ & $\begin{array}{c}\text { Romashkinskoe } \\
\text { Oilfield, } \\
\text { Almetievskaya Bed }\end{array}$ & $\begin{array}{c}\text { Vostochno-Anzirskoe } \\
\text { Oilfield }\end{array}$ \\
\hline Horizon/sedimentation & Bobrikovsky & Bashkirian deposits & Devonian & Kynovsky \\
\hline Lithology & $\begin{array}{l}\text { Terrigenous, } \\
\text { sandstone }\end{array}$ & $\begin{array}{l}\text { Organogenic } \\
\text { limestones with } \\
\text { sandstone and } \\
\text { dolomites }\end{array}$ & $\begin{array}{c}\text { Terrigenous, } \\
\text { sandstone, siltstone }\end{array}$ & Terrigenous, sandstone \\
\hline $\begin{array}{l}\text { Average depth below } \\
\text { sea level, } \mathrm{m}\end{array}$ & 1225 & 830 & $1640-1650$ & 1586 \\
\hline Average porosity, $\%$ & 24.0 & 12.8 & 18.0 & 20.5 \\
\hline $\begin{array}{l}\text { Average permeability, } \\
\mu \mathrm{m}^{2}\end{array}$ & 0.479 & 0.278 & 0.400 & 0.176 \\
\hline $\begin{array}{l}\text { Effective oil-saturated } \\
\text { reservoir capacity, m }\end{array}$ & 2.0 & $3.2-12.8$ & 3.0 & 2.4 \\
\hline $\begin{array}{l}\text { The formation } \\
\text { temperature, }{ }^{\circ} \mathrm{C}\end{array}$ & $20.2-21.3$ & 20 & 40 & 23.3 \\
\hline $\begin{array}{l}\text { Oil density in surface } \\
\text { condition, } \mathrm{kg} / \mathrm{m}^{3} \\
\left(20^{\circ} \mathrm{C}\right)\end{array}$ & 0.932 & 0.924 & 0.813 & 0.856 \\
\hline $\begin{array}{c}\text { Oil viscosity in } \\
\text { reservoir condition, } \\
\mathrm{mm}^{2} / \mathrm{sec}\end{array}$ & 72.6 & $43.9-161.9$ & $3.5-6.5$ & $19-86.2$ \\
\hline Water cut (average), $\%$ & 51 & 68 & 89 & 33 \\
\hline
\end{tabular}


Table A2. Rates of sulfate reduction and methanogenesis in production water of the Arkhangelskoe oilfield.

\begin{tabular}{|c|c|c|c|c|c|c|}
\hline \multirow{2}{*}{ Well No. } & \multicolumn{3}{|c|}{ Concentration, $\mathrm{mg} \cdot \mathrm{l}^{-1}$} & \multicolumn{2}{|c|}{$\begin{array}{l}\text { Methanogenesis Rate, } \\
\mathrm{nl} \mathrm{CH}_{4} \cdot \mathrm{L}^{-1} \cdot \text { day }^{-1} \text { from }\end{array}$} & \multirow{2}{*}{$\begin{array}{c}\text { Sulfate Reduction } \\
\text { Rate, } \text { ng S }^{2-} \\
\mathrm{L}^{-1} \cdot \text { day }^{-1}\end{array}$} \\
\hline & $\mathrm{HCO}_{3}^{-}$ & Acetate & $\mathrm{SO}_{4}{ }^{2-}$ & $\mathrm{HCO}_{3}{ }^{-}$ & Acetate & \\
\hline 4308 & 122 & 1.8 & 439 & 0 & 67.2 & 0 \\
\hline 4634 & 573 & 38 & 1504 & 0 & 1722 & 2610 \\
\hline 4647A & 305 & 1.2 & 960 & 0 & 0 & 0 \\
\hline 7492 & 708 & 6.1 & 1579 & 0 & 0 & 0 \\
\hline 7806 & 622 & 1.8 & 804 & 0 & 8.4 & 750 \\
\hline
\end{tabular}

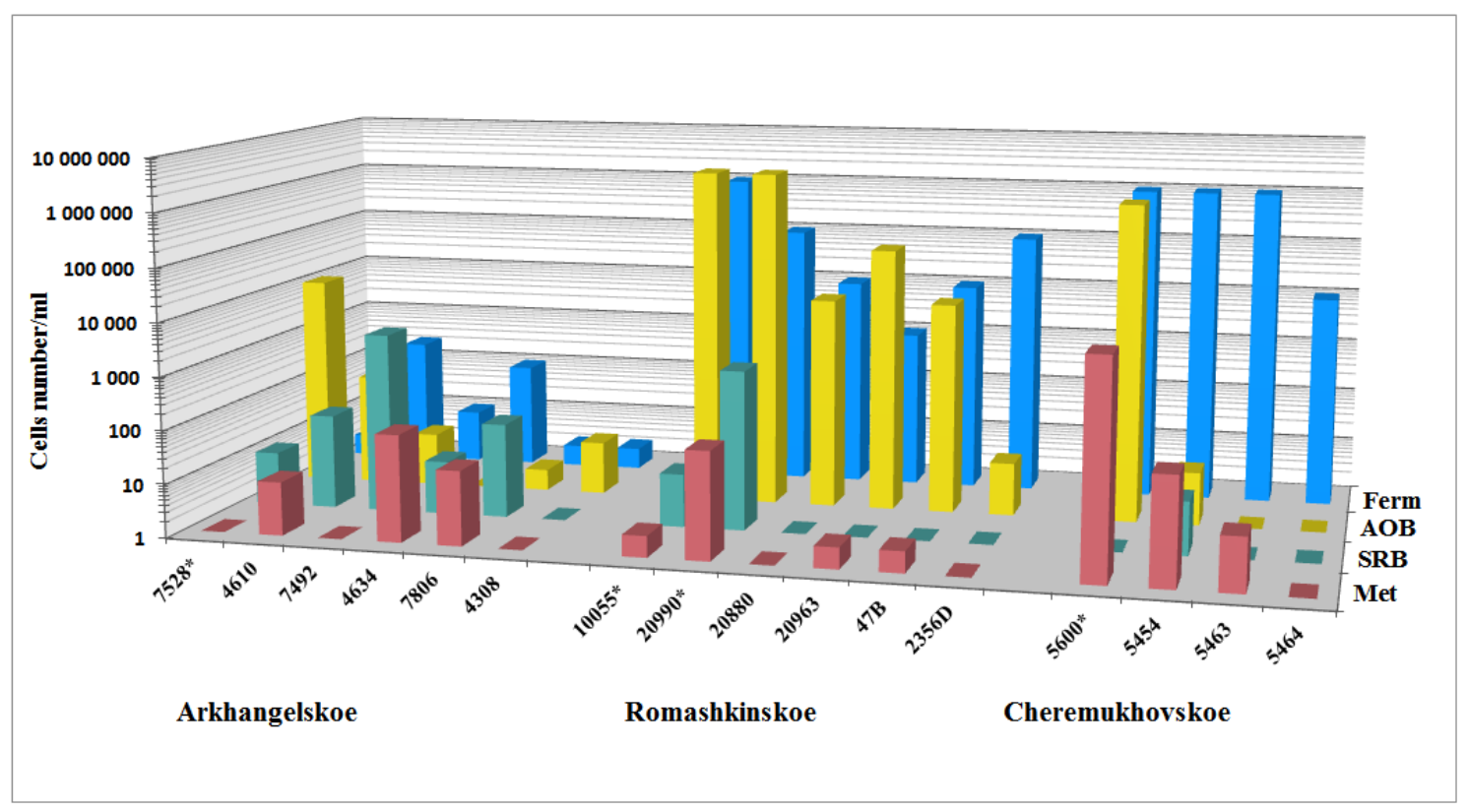

Figure A1. Numbers of aerobic and anaerobic microorganisms in injection and production water samples from the Arkhangelskoe, Romashkinskoe and Cheremukhovskoe oilfields. Designations: Ferm-fermentative bacteria, AOB—aerobic organotrophic bacteria, SRB—sulfate-reducing bacteria, Met-methanogenic archaea. Injection well marked with *, the rest are production wells. 

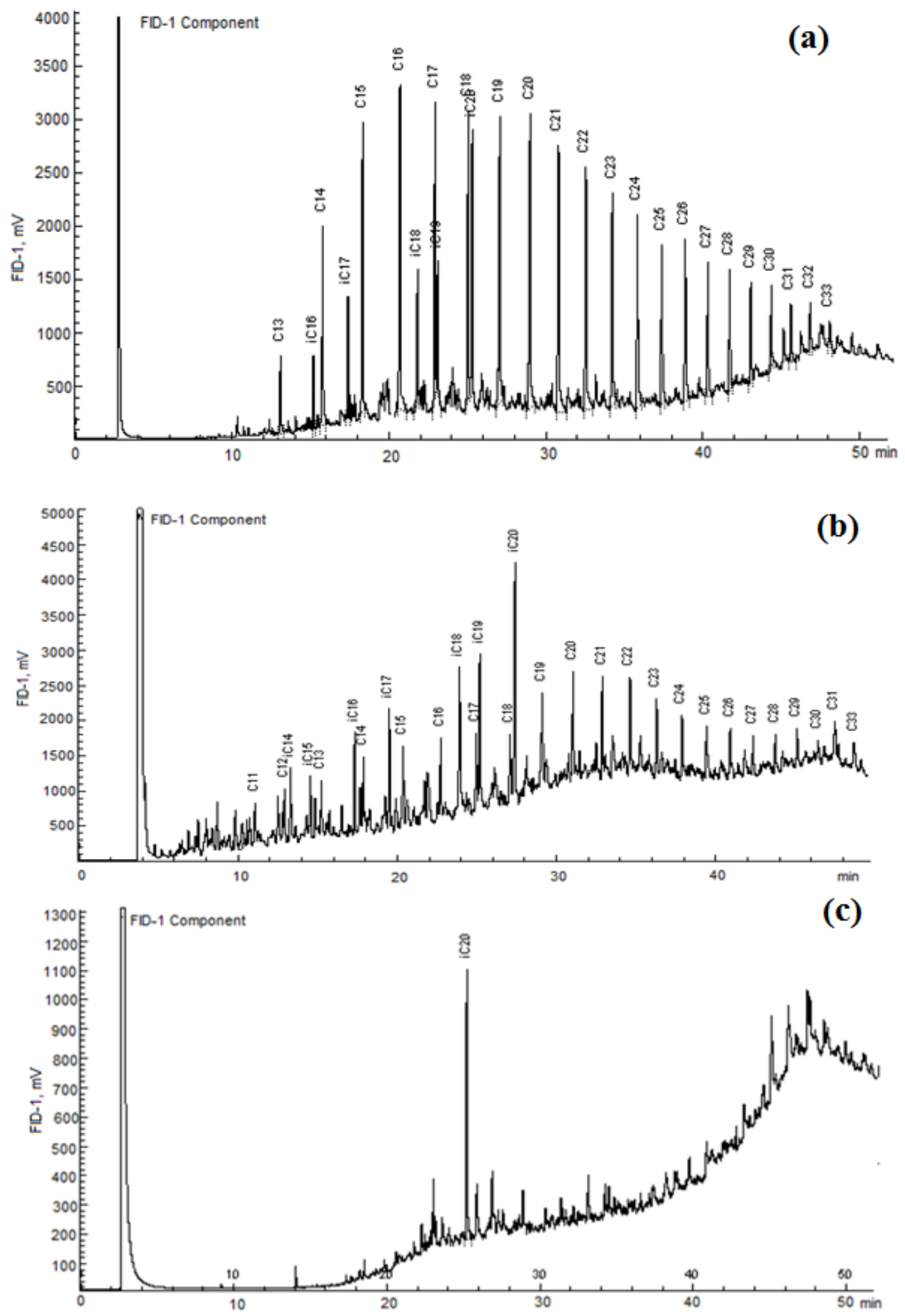

Figure A2. Chromatograms of $n$-alkanes of heavy oil from well 5452 (control, a), oil degraded by Gordonia amicalis strain 6-1 (b) and by Rhodococcus erythropolis HO-KS22 (c). Strains were incubated in the presence of $10 \mathrm{~g}$ oil L $\mathrm{L}^{-1}$. Strain 6-1 was incubated for 20 days at $23^{\circ} \mathrm{C}$, strain $\mathrm{HO}-\mathrm{KS} 22$ for 7 days at $28^{\circ} \mathrm{C}$. 

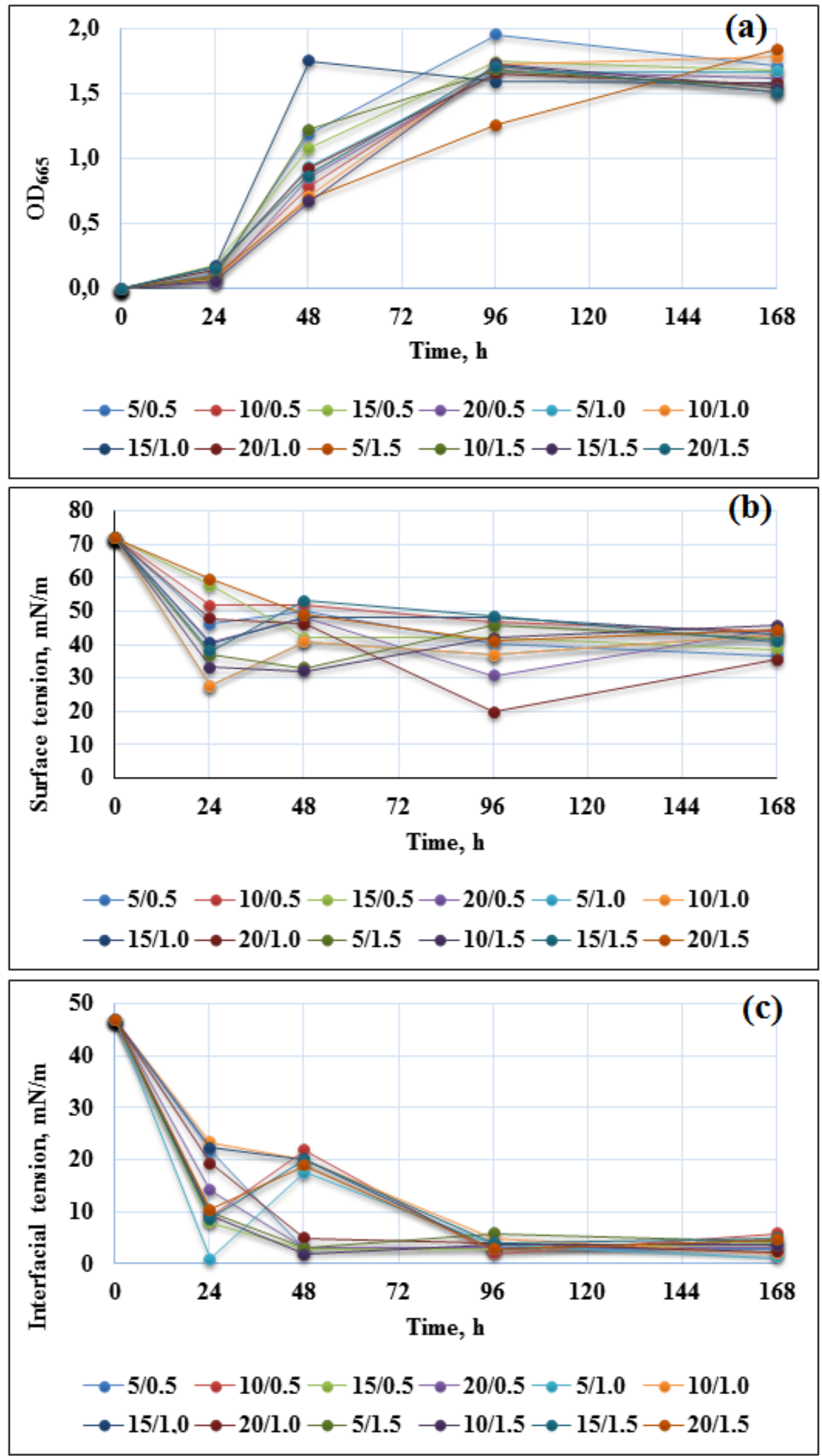

Figure A3. Accumulation of biomass $\left(\mathrm{OD}_{665}\right.$, a) by G. amicalis 6-1 strain in media with different glucose-nitrate ratios $\left(\mathrm{g} / \mathrm{g}\right.$ in $\left.\mathrm{L}^{-1}\right)$ and change of surface tension $(\mathbf{b})$ and interfacial tension of media against hexadecane (c) in dynamic. 


\section{References}

1. Belyaev, S.S.; Borzenkov, I.A.; Nazina, T.N.; Rozanova, E.P.; Glumov, I.F.; Ibatullin, R.R.; Ivanov, M.V. Use of microorganisms in the biotechnology for the enhancement of oil recovery. Microbiology 2004, 73, 590-598. [CrossRef]

2. Youssef, N.; Elshahed, M.S.; McInerney, M.J. Microbial processes in oil fields: Culprits, problems and opportunities. Adv. Appl. Microbiol. 2009, 66, 141-251. [PubMed]

3. Head, I.M.; Jones, D.M.; Larter, S. Biological activity in the deep subsurface and the origin of heavy oil. Nature 2003, 426, 344-352. [CrossRef] [PubMed]

4. Head, I.M.; Gray, N.D.; Larter, S.R. Life in the slow lane; biogeochemistry of biodegraded petroleum containing reservoirs and implications for energy recovery and carbon management. Front. Microbiol. 2014, 5, 566. [CrossRef] [PubMed]

5. Jones, D.M.; Head, I.M.; Gray, N.D.; Adams, J.J.; Rowan, A.K.; Aitken, C.M.; Bennett, B.; Huang, H.; Brown, A.; Bowler, B.F.J.; et al. Crude oil biodegradation via methanogenesis in subsurface petroleum reservoirs. Nature 2008, 451, 176-180. [CrossRef]

6. Gieg, L.M.; Davidova, I.A.; Duncan, K.E.; Suflita, J.M. Methanogenesis, sulfate reduction and crude oil biodegradation in hot Alaskan oilfields. Environ. Microbiol. 2010. Environ. Microbiol. 2010, 12, 3074-3086. [CrossRef]

7. Gray, N.D.; Sherry, A.; Hubert, C.; Dolfing, J.; Head, I.M. Methanogenic degradation of petroleum hydrocarbons in subsurface environments: Remediation, heavy oil formation, and energy recovery. Adv. Appl. Microbiol. 2010, 72, 137-161. [CrossRef] [PubMed]

8. Mbadinga, S.M.; Li, K.-P.; Zhou, L.; Wang, L.-Y.; Yang, S.-Z.; Liu, J.-F.; Gu, J.-D.; Mu, B.-Z. Analysis of alkane-dependent methanogenic community derived from production water of a high-temperature petroleum reservoir. Appl. Microbiol. Biotechnol. 2012, 96, 531-542. [CrossRef]

9. Jiménez, N.; Morris, B.E.L.; Cai, M.; Gründger, F.; Yao, J.; Richnow, H.H.; Krüger, M. Evidence for in situ methanogenic oil degradation in the Dagang oil field. Org. Geochem. 2012, 52, 44-54. [CrossRef]

10. Hubert, C.R.J.; Oldenburg, T.B.P.; Fustic, M.; Gray, N.D.; Larter, S.R.; Penn, K.; Rowan, A.K.; Seshadri, R.; Sherry, A.; Swainsbury, R.; et al. Massive dominance of Epsilonproteobacteria in formation waters from a Canadian oil sands reservoir containing severely biodegraded oil. Environ. Microbiol. 2012, 14, 387-404. [CrossRef] [PubMed]

11. Nazina, T.N.; Shestakova, N.M.; Grigor'yan, A.A.; Mikhailova, E.M.; Tourova, T.P.; Poltaraus, A.B.; Feng, Q.; Ni, F.; Belyaev, S.S. Phylogenetic diversity and activity of anaerobic microorganisms of high-temperature horizons of the Dagang oil field (P. R. China). Microbiology 2006, 75, 55-65. [CrossRef]

12. Nazina, T.N.; Shestakova, N.M.; Semenova, E.M.; Korshunova, A.V.; Kostrukova, N.K.; Tourova, T.P.; Min, L.; Feng, Q.; Poltaraus, A.B. Diversity of metabolically active Bacteria in water-flooded high-temperature heavy oil reservoir. Front. Microbiol. 2017, 8, 707. [CrossRef] [PubMed]

13. Cai, M.; Chan, Y.C.; Wang, R.; Si, Y.; Masakorala, K.; Yuan, H.; Yao, J.; Zhang, J. Effects of oxygen injection on oil biodegradation and biodiversity of reservoir microorganisms in Dagang oil field, China. Int. Biodeter. Biodegr. 2015, 98, 59-65. [CrossRef]

14. Voordouw, G.; Grigoryan, A.A.; Lambo, A.; Lin, S.; Park, H.; Jack, T.R.; Coombe, D.; Clay, B.; Zhang, F.; Ertmoed, R.; et al. Sulfide remediation by pulsed injection of nitrate into a low temperature Canadian heavy oil reservoir. Environ. Sci. Technol. 2009, 43, 9512-9518. [CrossRef] [PubMed]

15. Al-Bahry, S.N.; Elshafie, A.E.; Al-Wahaibi, Y.M.; Al-Bemani, A.S.; Joshi, S.J.; Al-Maaini, R.A.; Al-Alawai, W.J.; Sugai, Y.; Al-Mandhari, M. Microbial consortia in Oman oil fields: A possible use in enhanced oil recovery. J. Microbiol. Biotechnol. 2013, 23, 106-117. [CrossRef] [PubMed]

16. Al-Wahaibi, Y.; Al-Hadrami, H.; Al-Bahry, S.; Elshafie, A.; Al-Bemani, A.; Joshi, S. Residual oil recovery via injection of biosurfactant and chemical surfactant following hot water injection in Middle East heavy oil field. In Proceedings of the SPE Heavy Oil Conference, Calgary, AB, Canada, 11-13 June 2013; pp. 1-10.

17. Al-Sayegh, A.; Al-Wahaibi, Y.; Al-Bahry, S.; Elshafie, A.; Al-Bemani, A.; Joshi, S. Microbial enhanced heavy crude oil recovery through biodegradation using bacterial isolates from an Omani oil field. Microb. Cell Fact. 2015, 14, 141. [CrossRef] [PubMed] 
18. Nazina, T.N.; Grigor'yan, A.A.; Shestakova, N.M.; Babich, T.L.; Pavlova, N.K.; Ivoilov, V.S.; Belyaev, S.S.; Ivanov, M.V.; Feng, Q.; Ni, F.; et al. MEOR study enhances production in a high-temperature reservoir. World Oil 2008, 229, 97-101.

19. Nazina, T.N.; Pavlova, N.K.; Ni, F.; Shestakova, N.M.; Ivoilov, V.S.; Feng, Q.; Dongyun, Z.; Prusakova, T.S.; Belyaev, S.S.; Ivanov, M.V. Regulation of geochemical activity of microorganisms in a petroleum reservoir by injection of $\mathrm{H}_{2} \mathrm{O}_{2}$ or water-air mixture. Microbiology 2008, 77, 324-333. [CrossRef]

20. Nazina, T.N.; Feng, O.; Kostryukova, N.K.; Shestakova, N.M.; Babich, T.L.; Ni, F.; Wang, J.; Min, L.; Ivanov, M.V. Microbiological and production characteristics of the Dagang high-temperature heavy oil reservoir (block no. 1) during trials of the biotechnology for enhanced oil recovery. Microbiology 2017, 86, 653-665. [CrossRef]

21. Shestakova, N.M.; Ivoilov, V.S.; Tourova, T.P.; Belyaev, S.S.; Poltaraus, A.B.; Nazina, T.N. Application of Clone Libraries: Syntrophic Acetate Degradation to Methane in a HighTemperature Petroleum Reservoir: Culture-Based and 16S rRNA Genes Characterization. In Applied Microbiology and Molecular Biology in Oil Field Systems; Whitby, C., Skovhus, T.L., Eds.; Springer: Dordrecht, The Netherland, 2010; Chapter 6; pp. 45-53.

22. Chai, L.; Zhang, F.; She, Y.; Banat, I.M.; Hou, D. Impact of a microbial-enhanced oil recovery field trial on microbial communities in a low-temperature heavy oil reservoir. Nat. Environ. Pollut. Technol. 2015, 14, 455-462.

23. Nazina, T.N.; Sokolova, D.S.; Babich, T.L.; Semenova, E.M.; Ershov, A.P.; Bidzhieva, S.K.; Borzenkov, I.A.; Poltaraus, A.B.; Khisametdinov, M.R.; Tourova, T.P. Microorganisms of low-temperature heavy oil reservoirs (Russia) and their possible application for enhanced oil recovery. Microbiology 2017, 86, 773-785. [CrossRef]

24. Bonch-Osmolovskaya, E.A.; Miroshnichenko, M.L.; Lebedinsky, A.V.; Chernyh, N.A.; Nazina, T.N.; Ivoilov, V.S.; Belyaev, S.S.; Boulygina, E.S.; Lysov, Y.P.; Perov, A.N.; et al. Radioisotopic, culture-based, and oligonucleotide microchip analyses of thermophilic microbial communities in a continental high-temperature petroleum reservoir. Appl. Environ. Microbiol. 2003, 69, 6143-6151. [CrossRef] [PubMed]

25. Edgar, R.C. UPARSE: Highly accurate OTU sequences from microbial amplicon reads. Nat. Methods 2013, 10, 996-998. [CrossRef] [PubMed]

26. Edgar, R.C. Search and clustering orders of magnitude faster than BLAST. Bioinformatics 2010, 26, $2460-2461$. [CrossRef] [PubMed]

27. Maidak, B.L.; Cole, J.R.; Lilburn, T.G.; Parker, C.T., Jr.; Saxman, P.R.; Stredwick, J.M.; Garrity, G.M.; Li, B.; Olsen, G.J.; Pramanik, S.; et al. The RDP (ribosomal database project) continues. Nucleic Acids Res. 2000, 28, 173-174. [CrossRef] [PubMed]

28. Metsalu, T.; Vilo, J. ClustVis: A web tool for visualizing clustering of multivariate data using Principal Component Analysis and heatmap. Nucleic Acids Res. 2015, 43, W566-W570. [CrossRef]

29. Oksanen, J.; Kindt, R.; Legendre, P.; O'Hara, B.; Stevens, M.H.H.; Oksanen, M.J.; Suggests, M.A.S.S. The vegan package. Community Ecol. Package 2007, 10, 631-637.

30. Nazina, T.N.; Sokolova, D.S.; Babich, T.L.; Semenova, E.M.; Borzenkov, I.A.; Bidzhieva, S.K.; Merkel, A.Y.; Khisametdinov, M.R.; Tourova, T.P. Phylogenetic diversity of microorganisms from the sludge of a biogas reactor processing oil-containing and municipal waste. Microbiology 2018, 87, 416-424. [CrossRef]

31. Pfennig, N.; Lippert, K.D. Über das vitamin B12-Bedürfnis phototropher Schweferelbakterien. Arch. Microbiol. 1966, 55, 245-256.

32. Borzenkov, I.A.; Milekhina, E.I.; Gotoeva, M.T.; Rozanova, E.P.; Belyaev, S.S. The properties of hydrocarbon-oxidizing bacteria isolated from the oilfields of Tatarstan, Western Siberia, and Vietnam. Microbiology 2006, 75, 66-72. [CrossRef]

33. Trüper, H.G.; Schlegel, H.G. Sulfur metabolism in Thiorhodaceae. I. Quantitative measurements on growing cells of Chromatium okenii. J. Microbiol. Serol. 1964, 30, 321-323.

34. Bidzhieva, S.K.; Sokolova, D.S.; Tourova, T.P.; Nazina, T.N. Bacteria of the genus Sphaerochaeta from low-temperature heavy-oil reservoirs (Russia). Microbiology 2018, 87, 757-765. [CrossRef]

35. Obraztsova, A.Y.; Shipin, O.V.; Bezrukova, L.V.; Belyaev, S.S. Properties of the coccoid methylotrophic methanogen, Methanococcoides euhalobius sp. nov. Microbiology 1987, 56, 523-527.

36. Davidova, I.A.; Harmsen, H.J.; Stams, A.J.; Belyaev, S.S.; Zehnder, A.J. Taxonomic description of Methanococcoides euhalobius and its transfer to the Methanohalophilus genus. Antonie Van Leeuwenhoek 1997, 71, 313-318. [CrossRef] [PubMed] 
37. Collins, M.D.; Lund, B.M.; Farrow, J.A.E.; Schleifer, K.H. Chemotaxonomic study of an alkalophilic bacterium, Exiguobacterium aurantiacum gen. nov., sp. nov. J. Gen. Microbiol. 1983, 129, 2037-2042. [CrossRef]

38. Bazylinski, D.A.; Williams, T.J.; Lefevre, C.T.; Berg, R.J.; Zhang, C.L.; Bowser, S.S.; Dean, A.J.; Beveridge, T.J. Magnetococcus marinus gen. nov., sp. nov., a marine, magnetotactic bacterium that represents a novel lineage (Magnetococcaceae fam. nov., Magnetococcales ord. nov.) at the base of the Alphaproteobacteria. Int. J. Syst. Evol. Microbiol. 2013, 63, 801-808. [CrossRef]

39. Hahn, M.W. Isolation of strains belonging to the cosmopolitan Polynucleobacter necessarius cluster from freshwater habitats located in three climatic zones. Appl. Environ. Microbiol. 2003, 69, 5248-5254. [CrossRef]

40. Carini, P.; Steindler, L.; Beszteri, S.; Giovannoni, S.J. Nutrient requirements for growth of the extreme oligotroph 'Candidatus Pelagibacter ubique' HTCC1062 on a defined medium. ISME J. 2012, 7, 592-602. [CrossRef]

41. Francy, D.S.; Thomas, J.M.; Raymond, R.L.; Ward, C.H. Emulsification of hydrocarbons by subsurface bacteria. J. Ind. Microbiol. 1991, 8, 237-246. [CrossRef]

42. Borzenkov, I.A.; Sokolova, D.S.; Nazina, T.N.; Babich, T.L.; Semenova, E.M.; Ershov, A.P.; Khisametdinov, M.R. Gordonia amicalis Strain with Ability of Generation Directly in Oil Reservoir of Oil-Displacing Agent-BioPAV and Decreasing Content of Organosulfur Compounds of Oil. Patent RU No. 2673747 C1, 29 November 2018. (In Russian). Available online: http://www1.fips.ru/fips_servl/fips_servlet?DB=RUPAT\&DocNumber= 2673747\&TypeFile=html (accessed on 29 November 2018).

43. Bubela, B. Geological implications and their effect on the realization of MEOR. In Proceedings of the First International MEOR Workshop, 1-3 April 1986; King, J.W., Stevens, D.D., Eds.; Hardin-Simmons Univ.: Abilene, TX, USA, 1987; pp. 79-88.

44. Nazina, T.N.; Ivanova, A.E.; Wagner, M.; Ziran, B.; Ibatullin, R.R.; Kandaurova, G.F.; Miller, Y.M.; Belyaev, S.S.; Ivanov, M.V. Introduction of Clostridium tyrobutyricum and molasses into the oil stratum of the Romashkinskoe oilfield and its influence on microbial processes in the stratum. Microbiology 1996, 65, 355-359.

45. Nazina, T.N.; Ivanova, A.E.; Ivoilov, V.S.; Miller, Y.M.; Kandaurova, G.F.; Ibatullin, R.R.; Belyaev, S.S.; Ivanov, M.V. Results of the trial of the microbiological method for the enhancement of oil recovery at the carbonate collector of the Romashkinskoe oil field: Biogeochemical and production characteristics. Microbiology 1999, 68, 222-226.

46. Blinkova, E.V.; Eliseev, E.I. Dissolution of Calcium carbonate in aqueous solutions of acetic acid. Russ. J. Appl. Chem. 2005, 78, 1064-1066. 